\title{
The Nutrition Transformation: From Undernutrition to Obesity
}

\subsection{INTRODUCTION}

As structural transformation changes countries from subsistence agriculture economies to modernized economies, countries undergo a nutrition-related transition ${ }^{1}$ (Griffiths \& Bentley, 2001). High rates of undernutrition $^{2}$ come down and population health improves. However, even as undernutrition decreases, experiences of some countries in the recent past have shown that obesity rates may increase due to overnutrition $^{3}$ and this can decrease overall gains made to health during the

${ }^{1}$ In the previous chapter, we use the definition of the nutrition transition as described in Popkin (1997), which refers to the dietary transformation that are related to ST. In this chapter the nutrition transformation refers to the changing burden of nutrition-related health problems that constitute the triple burden of malnutrition-we build on the Griffiths and Bentley (2001) conceptualization here.

${ }^{2}$ At its broadest level, undernourished individuals are those who do not have access to one or more essential nutrients in their diets. Being undernourished, represented by individuals who are either underweight (too thin for their age), wasted (too thin for their height and age) or stunted (too short for their age) compared to a well-nourished reference population, is one type of undernourishment. Another type of undernourishment is called hidden hunger. This manifests itself as deficiencies of essential micronutrients such as vitamins or minerals in the human body.

${ }^{3}$ Over-nourished individuals, on the other hand, are those who consume an excess of a particular macronutrient-calories in particular. This condition is represented by overweight and obesity outcomes which are determined by the age, gender, height and weight of the individual in relation to a similar well-nourished group.

(C) The Author(s) 2019

P. Pingali et al., Transforming Food Systems for a Rising India, Palgrave Studies in Agricultural Economics and Food Policy, https://doi.org/10.1007/978-3-030-14409-8_5 
nutrition transition. When food systems focus narrowly on ensuring food security but do not think more broadly about ensuring nutrition security, this problem of obesity and hence malnutrition can become synonymous with the problem of poverty and low incomes. Thus, poor nourishment and poor health may increase during structural transformation. In India too, economic growth, agricultural development and a keen policy focus on nutrition-related health improvements have brought with it a reduction in hunger and undernutrition rates across the country. Between the NFHS I (1992-93) and NFHS IV (2015-16) surveys, undernutrition rates for children under the ages of five have fallen. The incidence of stunting has decreased by 13 percentage points, and underweight rates have decreased by 24 percentage points. Between NFHS III (2005-06) and NFHS IV (2015-16), the percentage of adult women and men who are underweight has decreased by $13 \mathrm{pp}$ and $15 \mathrm{pp}$ (respectively). However, within the last decade, the over-nutrition prevalence rate has doubled within the country (see Fig. 5.1). Given its close association with the incidence of noncommunicable diseases, this phenomenon has created new and serious challenges for the health of individuals. In the long term, increasing risks for malnutrition may have repercussions for economic development, agriculture and health.

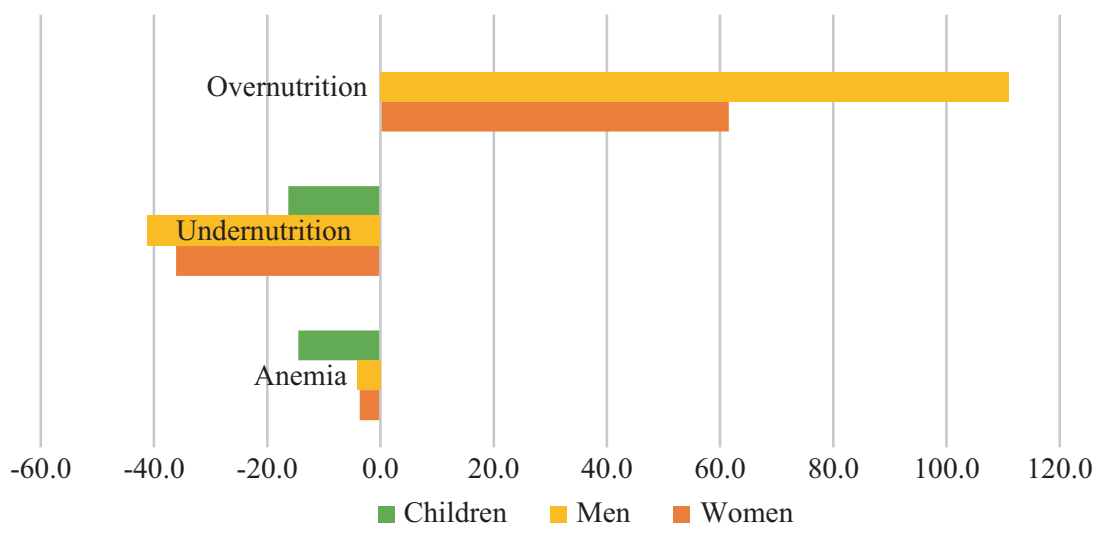

Fig. 5.1 Percentage point changes in the triple burden of malnutrition in India. Source: NFHS 2005-06 and NFHS 2015-16; based on authors calculations 
In the previous chapter, we have seen that the demand for food per capita, demand for diverse foods and demand for eating out has kept pace with rising per capita incomes. If food systems cannot respond appropriately to the growing demand for nutrients with an adequate supply response, this may reduce the effectiveness of current policy interventions in meeting their goals of lowering undernutrition and hidden hunger. Additionally, in Chaps. 2 and 3, we have seen that forces of ST have led to a divergence in the growth experience across regions and the agricultural and non-agricultural sectors. If food systems cannot address the problem of income inequality, this may impact a household's ability to access and purchase diverse and quality nutrients from markets. These factors have important (negative) implications for the Indian experience.

In this chapter, we explore the food system's role in reducing the triple burden of malnutrition ${ }^{4}$ and moving towards a healthier population. We bring forward evidence from the literature that illuminates the pathways through which malnutrition is impacted as well as discuss interventions from India that have been successful in reducing poor nutrition outcomes thus far. We also bring forward evidence from international contexts on other potential interventions available for reducing malnutrition and lay out different options that can help regulate the nutrition transition that we see unfolding in the country today.

\footnotetext{
${ }^{4}$ The triple burden of malnutrition encapsulates the coexistence of a large number of undernourished individuals side by side with over-nourished people in the presence of high levels of micronutrient deficiencies within a given population. At its broadest level, undernourished individuals are those who do not have access to one or more essential nutrients in their diets. Being undernourished manifests itself as individuals who are either underweight (too thin for their age), wasted (too thin for their height and age) or stunted (too short for their age) compared to a well-nourished reference population. Calorie deprivation and protein energy deficiency are some of the major causes of this type of undernourishment. Another type of undernourishment is called hidden hunger. This manifests itself as deficiencies of essential nutrients such as vitamins or minerals called micronutrients. Diseases such as anemia, night blindness, rickets, scurvy and so on are outcomes of these deficiencies. Overnourished individuals on the other hand are those who consume an excess of a particular macronutrient, calories in particular. This condition is represented by overweight and obesity outcomes.
} 


\subsection{Current State of the Triple Burden of Malnutrition in India}

The triple burden of malnutrition is particularly an acute problem for India. For one, the latest NFHS estimates show that around $30 \%$ were too thin for their age and gender (underweight) ${ }^{5}$ and $38 \%$ of all children under the ages of five were too short for their age and gender (stunted). With regard to the former, India did far worse regarding prevalence both across ST and when compared to other countries (Fig. 5.2). However, with regard to stunting indicators, it can be seen that poor states in India have comparable outcomes to countries from the SSA regions, while more developed states are closer to world averages (Fig. 5.3). Poor nutrition outcomes are known to lower cognitive skills, lower educational outcomes, lower productivity and lower wages in adults who were malnourished as children compared to adults who were not (Alderman, Hoddinott, \& Kinsey, 2006; Black et al., 2013; Chen \& Zhou, 2007; Hoddinott,

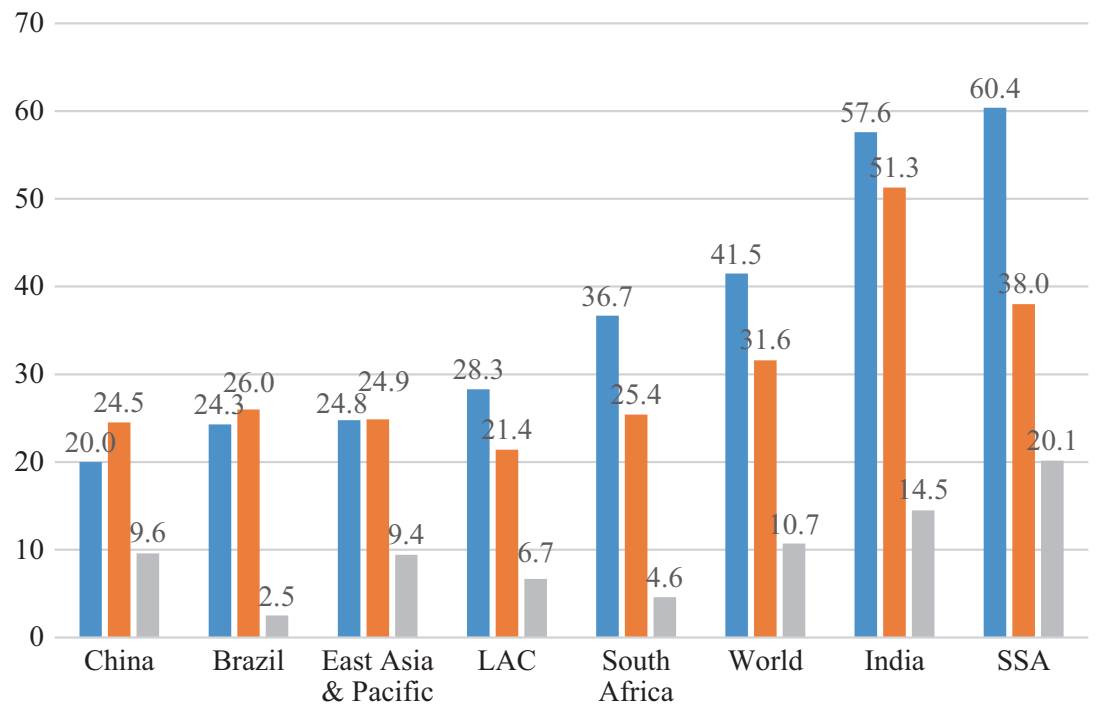

- Child Anemia $\quad$ Women Anemia $\square$ Undernourished

Fig. 5.2 International comparisons in the share of malnutrition (2015-16). Source: World Bank DataBank; based on authors calculations

${ }^{5}$ Most of the improvements came from moving people out of the severely malnourished cases into the moderately malnourished. 


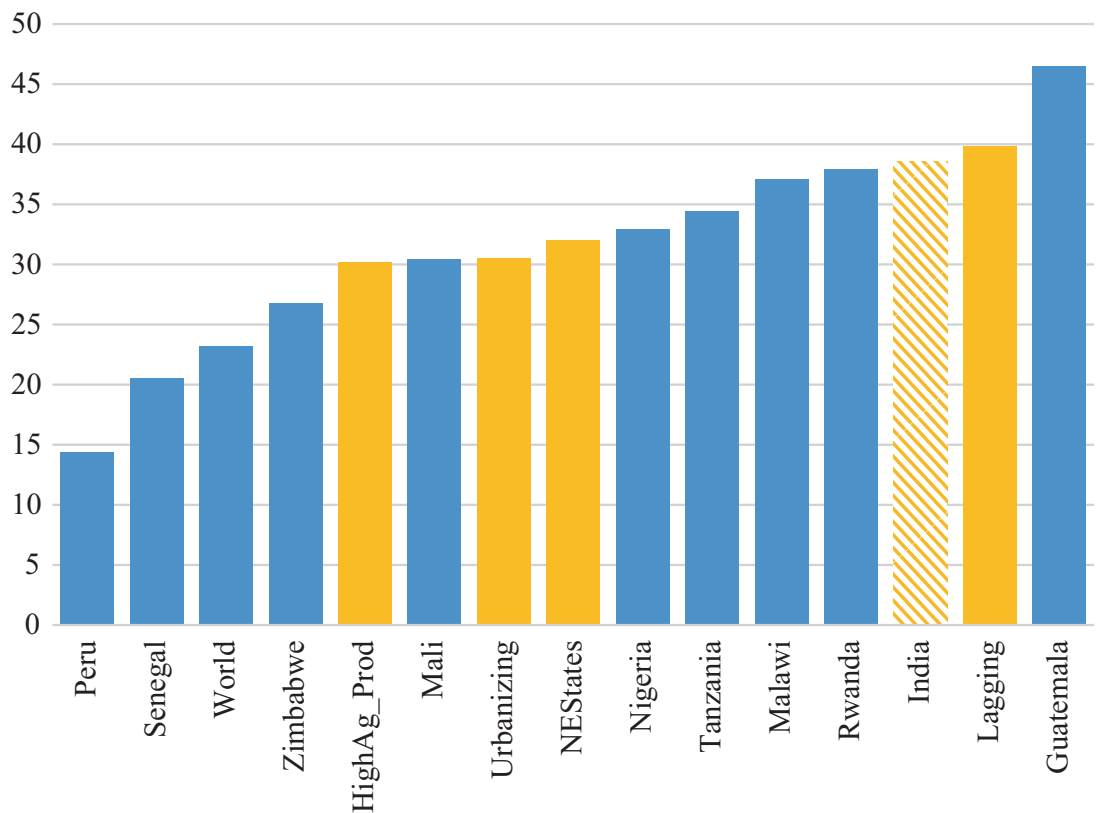

Fig. 5.3 Share of stunted children under 5 years (2015-16). Source: NFHS 2015-16 and World Bank DataBank; based on authors calculations

Maluccio, Behrman, Flores, \& Martorell, 2008; Roseboom, de Rooij, \& Painter, 2006; T. J. Roseboom et al., 2001; Victora et al., 2008; Akresh, Verwimp, \& Bundervoet, 2013; Gørgens, Meng, \& Vaithianathan, 2012; Lumey et al., 2007; Stein et al., 2008). In addition to greater mortality risks for children, studies have also shown that adults who were undernourished in childhood have greater incidence of non-communicable diseases than those who were properly fed (Chen \& Zhou, 2007; Gørgens, 2002; T. Roseboom et al., 2006). While one can still argue that there has been progress towards reducing stunting, underweight between the 2005 and 2015 National Family Health Surveys (NFHS) across all levels of state-wise development, the incidence of wasting has increased during this time (Fig. 5.4). Wasting occurs when children are too thin for their respective heights, ages and gender. This indicator has been correlated with lower access to food in the short term as well as increased mortality risks for children under the ages of five. An increase in this indicator reflects the speed of, or lack thereof, progress in comprehensively reducing food insecurity and undernutrition within the country. 


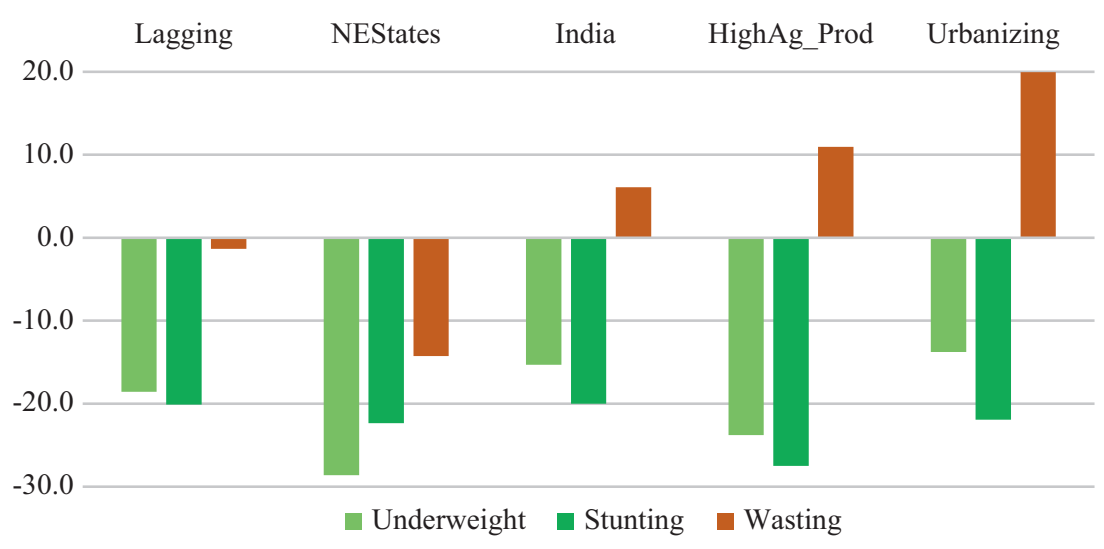

Fig. 5.4 Percentage change in the undernutrition in children under five by state classification. Source: NFHS 2005-06 and NFHS 2015-16; based on authors calculations

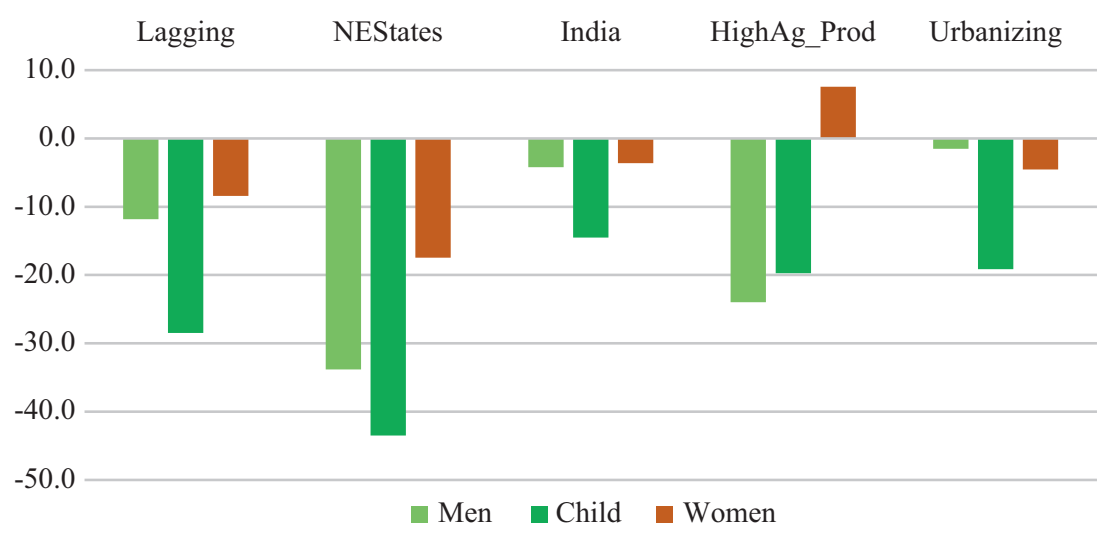

Fig. 5.5 Percentage change in anemia prevalence by state classifications. Source: NFHS 2005-06 and NFHS 2015-16; based on authors calculations

Two, the problem of hidden hunger, or micronutrient deficiency, in India continues to remain acute. For example, the current incidence rates of anemia for men $(23 \%)$, women (53\%) and children (58\%) are higher than incidence rates of the same group of individuals in poor countries such as those in subSaharan Africa (Fig. 5.5). Of those who are anemic, iron deficiency anemia (IDA) is believed to affect around $60 \%$ of all individuals (Murray et al., 2012). 
This disease has been correlated with greater fatigue and lower productivity. Other essential nutrients such as iodine and vitamin A too, that are important inputs into biological processes, have not yet been able to find a way into the Indian diet (Jha, Gaiha, \& Sharma, 2009). For women in India, reducing anemia continues to remain extremely difficult to tackle compared to other groups. Between the NFHS III \& IV, anemia incidence decreased by 3.6 percentage points for non-pregnant women in comparison to men whose anemia decreased by 4.2 percentage points. Both these groups were not targeted for any interventions. In states which have had a history of high productive agricultural systems, anemia rates of women have increased during this time. This is a cause of concern given that this micronutrient deficiency has been linked with higher maternal mortality in adults as well as lower cognitive development and higher infant mortality rates (Akhtar et al., 2013; Allen, Peerson, \& Olney, 2009; Bobonis, Miguel, \& Sharma, 2004; Brabin, Hakimi, \& Pelletier, 2001; Jones et al., 2016; Rasmussen, 2001).

Three, while the country continues to grapple with the problem of undernutrition, experts have called to attention the unprecedented increase in obesity rates, both in rural and urban areas in the country (R. Jha et al., 2009; Meenakshi, 2016; P. Pingali, 2007; Popkin, 1997, 1999; Sengupta, Angeli, Syamala, Dagnelie, \& Schayck, 2015; Sturm, Ringel, \& Andreyeva, 2004; Swinburn et al., 2011). Traditionally, obesity has been viewed as a luxury good associated with higher per capita incomes and a greater level of structural transformation (Popkin, 1997, 1999). However, obesity rates have increased at an alarming rate in the last ten years-doubled for men and increased by $62 \%$ for women (Fig. 5.6). Even across states, it would seem that poorer states are worse affected by the changes in obesity rates compared to richer states. Obesity is a known risk factor for non-communicable diseases (NCDs) such as diabetes, heart disease, cancer and other chronic diseases. Even in the country, higher incidence of high sugar is correlated with high obesity in states (Fig. 5.7). In the United states, in addition to health risks, obesity has also been found to explain lower incomes, productivity and wages in addition to lower long-term health (Alaimo, Olson, \& Frongillo, 2001; Cawley, 2015; Wang, McPherson, Marsh, Gortmaker, \& Brown, 2011).

The fourth but important characteristic of the malnutrition problem in India is that it remains a problem for women and children regardless of the level of economic development in the country. Even though multiple interventions have targeted changes to move the indicators on these groups, the stickiness of the problem is reflected both in economic outcomes and in the inequities remaining more or less constant over time. Regarding anemia prevalence, over-nutrition or even undernutrition, the 


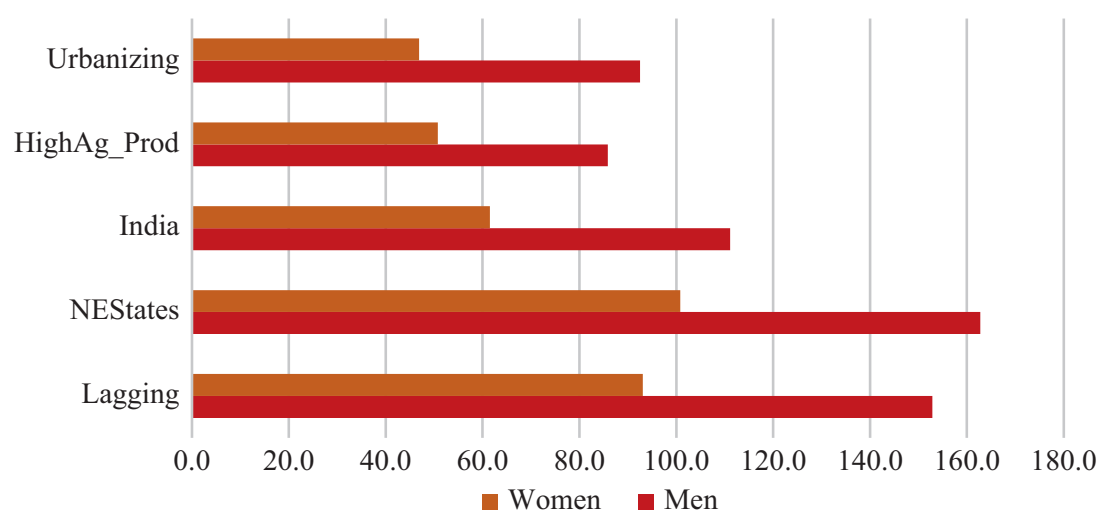

Fig. 5.6 Percentage change in obesity incidence by state classifications. Source: NFHS 2005-06 and NFHS 2015-16; based on authors calculations

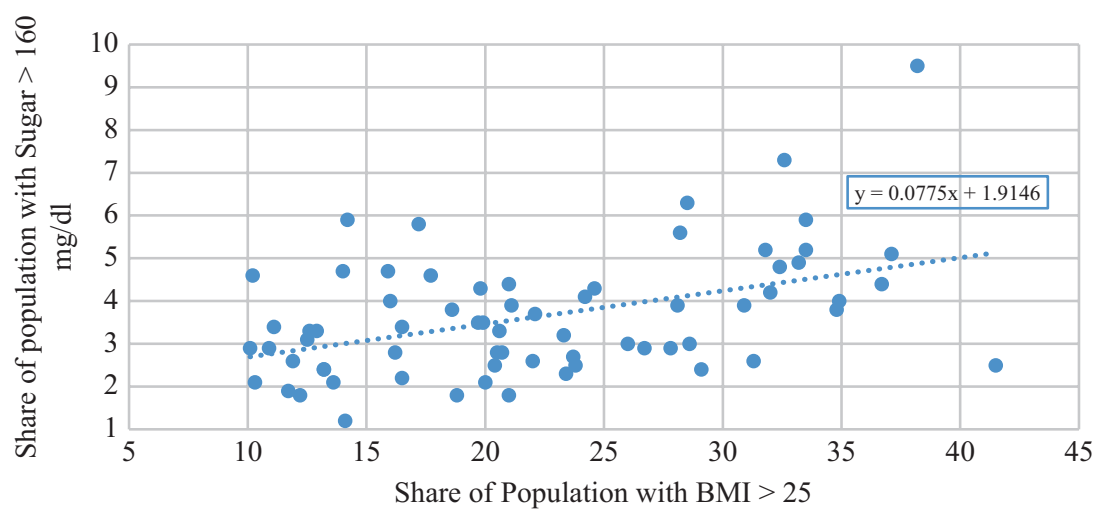

Fig. 5.7 Relationship between the risk of diabetes and over-nutrition in adults. Source: NFHS 2015-16; based on authors calculations

prevalence rates continue to remain the highest for these groups. When women are undernourished, research has found that this leads to low labor productivity, health and economic development of the household. This has negative intergenerational spillovers on the health of children for whom the woman is the major care giver. When children are undernourished in their childhood, this has been linked to poor adult education, health and productivity outcomes (Alderman et al., 2006; Almond \& Currie, 2011; Gutierrez, 2013; J. Hoddinott et al., 2008; J. A. Maluccio et al., 2009; Plessow et al., 2015). 


\subsection{Pathways Towards Better Nutrition Outcomes}

Policy makers and scientists around the world have learned that reducing malnutrition is not just about making more food or even more healthy food available for individuals to consume. There are many other channels through which individuals are prevented from accessing adequate food or nutrients. To capture the complexity of the problem of access, we build on the nutrition framework proposed by Pingali and Ricketts (2014) that encompasses the main pathways relevant in our food systems approach. At its broadest level, there are two main units of analysis in this framework-the household and the individual. Malnutrition arises from the lack of access to diverse diets for households. This arises due to the lack of availability of diverse foods in a local ecosystem (Fig. 5.10, quadrant 1 ) as well as due to income insecurity that impacts the affordability of a balanced diet (Fig. 5.10, quadrant 2). This translates into low food security and poor diet diversity across households and thus enhances risks involved in being malnourished. With regard to ensuring greater availability of diverse foods within a local ecosystem, corresponding nutrition and agriculturerelated interventions play an important role in access. Income uncertainty that arises from socio-economic disadvantages is known to limit households' ability to access foods. Thus interventions that create safety nets to protect households against income shocks can play a key role in improving access. Within households, intra-household dynamics (Fig. 5.10, quadrant 3) and the health environment (Fig. 5.10, quadrant 4) determine nutrition access and hence explain differences in nutrition outcomes between members. With regard to risk factors that arise from intra-household dynamics, age, gender, relationship to the head of household and so on play an important role in determining access to food. This dynamic is reflected in Figs. 5.8 and 5.9, where one sees that women and children have the highest rates of malnutrition compared to male members. Finally is the effect of the health environment which is impacted by disease burden as well as water and sanitation quality within households. By affecting human biological processes that help in the absorption of nutrition, a poor health environment becomes an important risk factor in determining malnutrition levels (Fig. 5.10). 


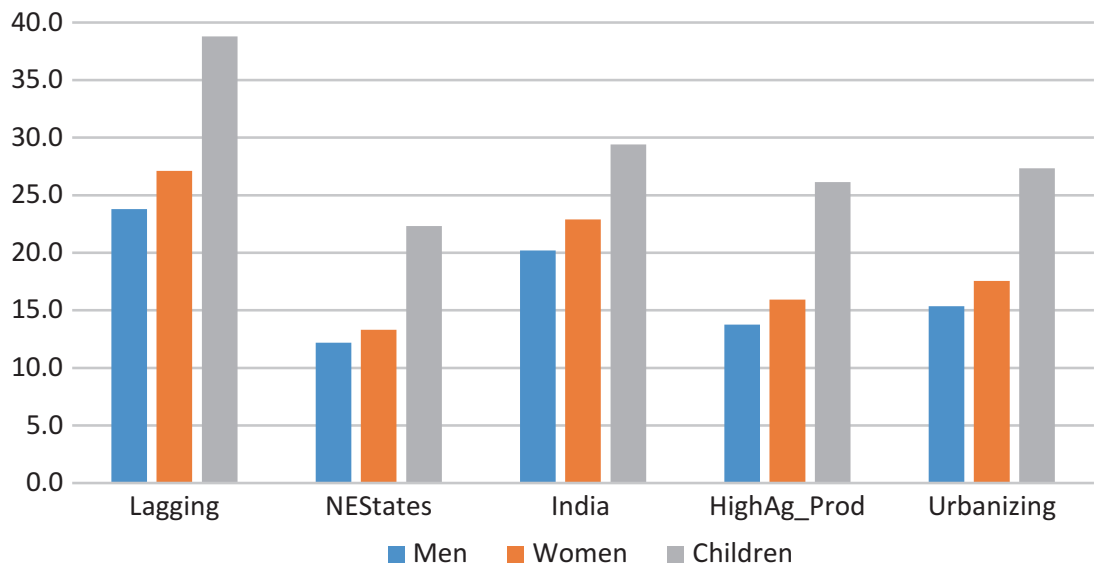

Fig. 5.8 Intra-household burden of undernutrition share by state classifications. Source: NFHS 2015-16; based on authors calculations

70.0

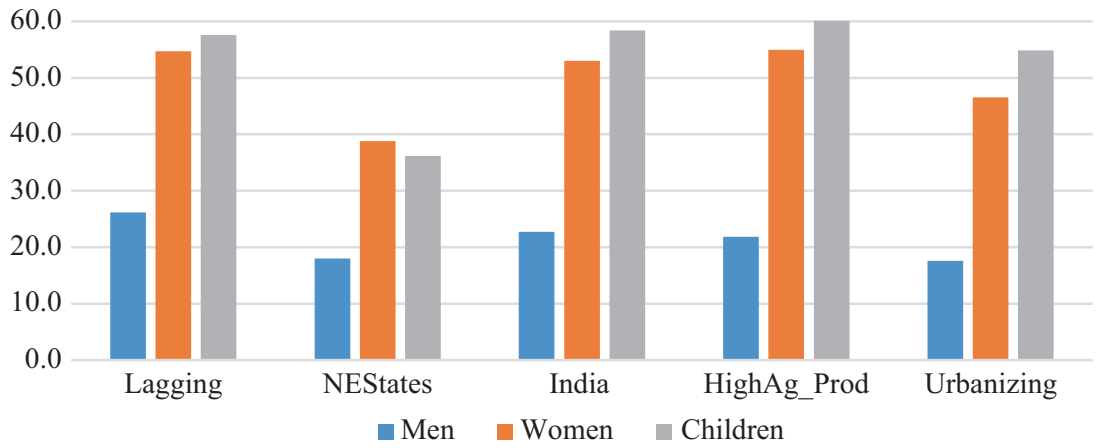

Fig. 5.9 Intra-household burden of anemia by state classification. Source: NFHS 2015-16; based on authors calculations

In this chapter, we add the effects of the growing incidence of NCDs, rising economic inequality and threats from climate change to the framework. NCDs can directly reduce individuals' ability to absorb food by impacting their health. If women are more susceptible to health shocks from NCDs, this can worsen the problem of access to nutrition and can also negatively impact children's health outcomes (Shetty et al., 2012). 


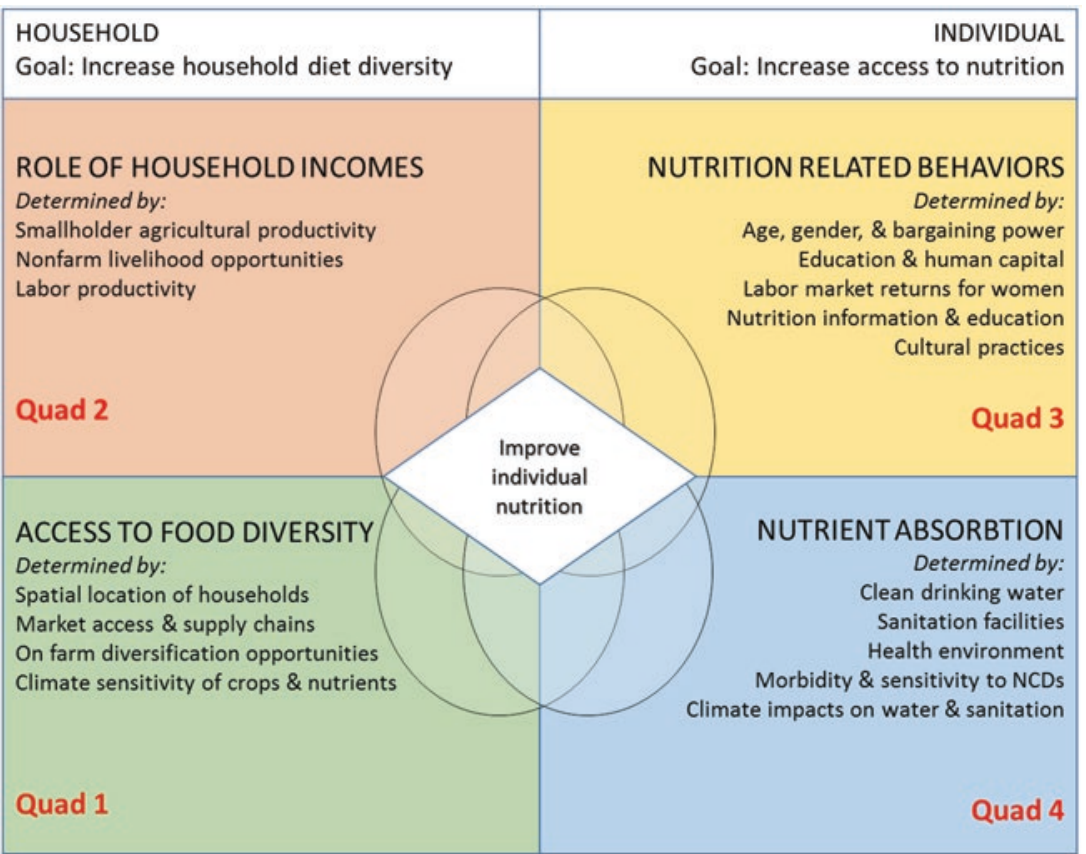

Fig. 5.10 Pathways to better nutrition

Increase in NCDs can also lower the productivity of household members, thus impacting how much food there would be available to consume. Exposure to secondary health risks increases the probability of catastrophic health episodes and thus reduces income security of households. An unanticipated health episode is known to be a major risk factor in the impoverishment of households (Krishna, 2011). Rising economic inequality reduces the number of economic opportunities available for households to participate in the process of development. This creates a self-reinforcing vicious cycle of low income and low ST. States with low ST do not have the institutional capacity to implement successful poverty alleviation programs. Given that labor is a major input into agricultural production in these regions, poor health of individuals in these states translates into low agricultural productivity. Poor health also prevents individuals from participating in economic development activities that may be available in high growth states, thus locking individuals and their respective states into a suboptimal equilibrium of 
poor health and poor economic development. This reduces the ability of states to participate in catch-up growth. Finally, threats from climate change have brought new, unanticipated negative spillovers to economic development, health and agriculture. By increasing uncertainty in agricultural production, climate change threatens to increase food price volatility, decrease access to food for poor households, decrease the nutrient content of crops as well as decrease the health environment. ${ }^{6}$ These shocks will threaten efforts made towards improving nutrition outcomes. In the next section, we summarize the evidence from the literature with regard to the pathways as well as the experience of these interventions along these pathways in enabling greater nutrition.

\subsection{Evidence on Pathways and Their Corresponding Food, Agriculture and Nutrition INTERVENTIONS}

\subsubsection{Pathways to Reduce Household Malnutrition Through Diet Diversification}

According to the Food and Agriculture Organization of the United Nations (FAO), "Dietary diversity is a qualitative measure of food consumption that reflects household access to a variety of foods, and is also a proxy for nutrient adequacy of the diet of individuals" (Kennedy, Ballard, \& Dop, 2011). Diet diversity of households is known to be correlated with better nutrition (Arimond \& Ruel, 2004; Busert et al., 2016; J. Hoddinott \& Yohannes, 2002; Pingali \& Sunder, 2017; Popkin, Horton, Kim, Mahal, \& Shuigao, 2001; J. H. Rah et al., 2010). For example, increased dietary diversity has been associated with lower prevalence of hidden hunger and higher nutrient adequacy ratios for individuals (Arimond \& Ruel, 2004; Ruel, 2003; Steyn, Nel, Nantel, Kennedy, \& Labadarios, 2006). In households with greater consumption of animal-based products such as milk, eggs or meat, children who are not breastfed have lower stunting and wasting as well (Ruel, 2003). Lack of diet diversity has more recently been linked to a higher risk of obesity (Azadbakht \& Esmaillzadeh, 2011; Nicklas, Baranowski, Cullen, \& Berenson, 2001). Given this close relationship between dietary diversity of households and nutrition outcomes, ensuring that households can access diverse foods requires interventions at

\footnotetext{
${ }^{6}$ More evidence on these factors can be found in the chapter on climate change.
} 
two levels. First is to ensure that there is greater availability of food diversity within the local system. The second set of interventions would need to improve the affordability of these diets. In this section, we discuss the various interventions that have been currently implemented in India with regard to improving nutrition by targeting household diet diversity.

\subsubsection{Improving Access to Food Diversity}

In India, staple grain policy has subsidized the production of calorie dense foods (P. Pingali, 2015). While these policies have successfully increased staple grain productivity and hence economic outcomes and nutrition in some parts of the country, it has also led to a regional divergence in outcomes. Agricultural households from low ST areas have low cropping diversity, low ability to participate in markets as well as some of the worse nutrition outcomes in the country. Staple grain fundamentalism in agricultural policy has preoccupied policy makers in investing in productivity enhancing staple-grain-focused technologies at the cost of developing similar biotechnologies for non-staple crops (Pingali, 2012). This strategy has increased vulnerability in the production of non-staples, especially in areas which are not properly irrigated. As climate change threatens the production of crops, lack of technology for drought-resistant, heat-resistant and flood-resistant non-staples increases vulnerability of the same. ${ }^{7}$ On the demand side, as discussed in Chap. 4, the growth of the retail sector and organized sector and increased expenditures on non-staples reflects the increase in demand and hence willingness to spend on these goods. Urban dietary demand, for example, has been rising quite rapidly across all states, especially in those regions that are more developed (Fig. 5.11). Agricultural (rural) households too are spending a larger fraction of their incomes on non-staples (such as meat, pulses, fruits and vegetables) purchased from the markets (S. Subramanian \& Deaton, 1996; Deaton, 1987). These demand factors create non-trivial production challenges and challenges for their distribution. These supply and demand factors have important implications for the availability of nutrients and diverse foods at the household level. If climate shocks increase uncertainty in food production and hence increase volatility of food prices, poor households will be more vulnerable to shocks food security and hence malnutrition (Jensen, 2000).

Currently, research on the safety net programs such as the Mid-Day Meal Scheme (MDMS) and the Public Distribution System (PDS) have shown mixed results regarding their impact on improving household diet

\footnotetext{
${ }^{7}$ These factors are discussed in more detail in Chap. 7.
} 
1400

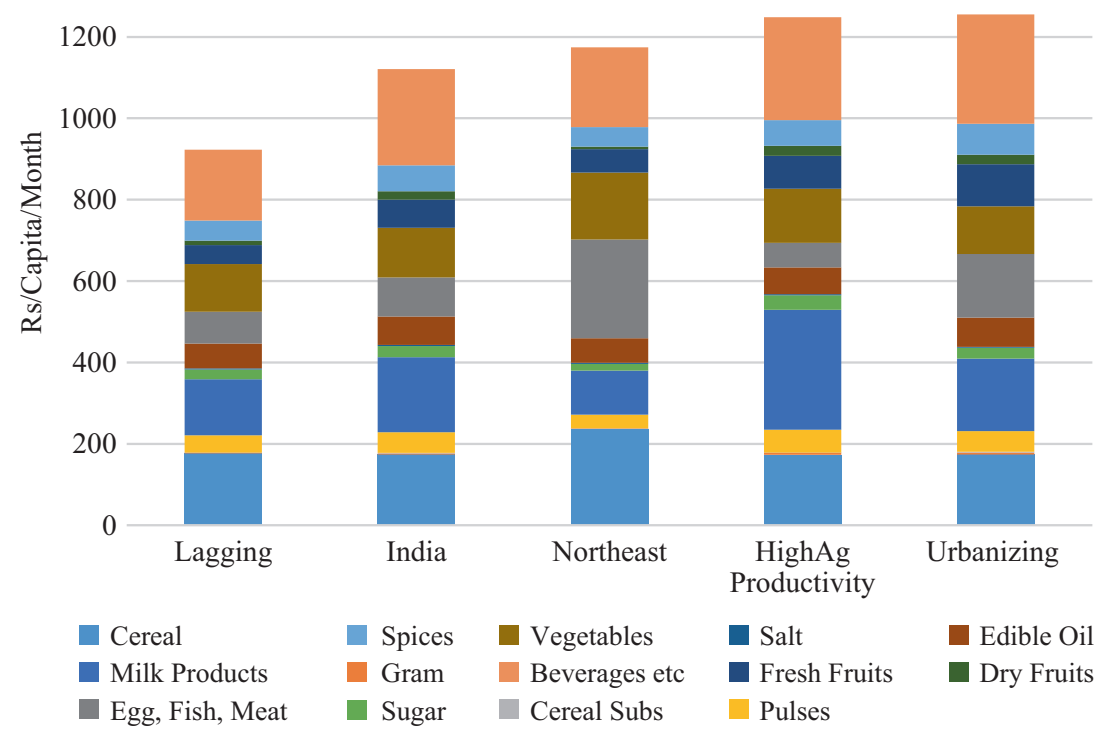

Fig. 5.11 Urban household dietary-spending patterns in India (2011-12). Source: Food Consumption Expenditure report NSSO 2011-12; based on authors calculations

diversity. Research on the Integrated Child Development Scheme (ICDS) program has shown it to be mildly effective in reducing undernutrition in children and mothers who are beneficiaries of the program. In areas where Anganwadi health workers have been compensated for performance, there has been greater short-term progress in addressing malnutrition (Dubowitz et al., 2007; P. Singh, 2015). Thus having a strong locally oriented health task force has been an important complementary investment required for improving undernutrition outcomes. Evaluations of the MDMS has shown its effectiveness in reducing undernutrition of school-aged children, especially from families who suffered from shocks such as droughts (Singh, Park, \& Dercon, 2013). Rahman (2016) and Kishore and Chakrabarti (2015) have linked universal access to the PDS with greater household diet diversity. However, in a study by Kaushal and Muchomba (2015), the author found that PDS access may not have a clear impact on nutrition outcomes. The challenges in implementation that have led to this mixed evidence on their impact will be discussed in more detail in the next chapter. 
On the other end of the malnutrition burden, research has shown that rising obesity and NCD prevalence has been linked to consumption of excessive carbohydrates and sugar in diets. Staple grain crops and sugar crops have been long favored by agricultural and PDS procurement policies in the country. By artificially keeping consumption prices low, experts have speculated that this has led to overconsumption of these foods in diets. According to Arora, Pillai, Dasgupta, and Garg (2014) increased consumption of sugar and fat products in diets is a major risk factor in explaining the rise in obesity in India. Anjana et al. (2015) found that increased intake of refined cereals was highly correlated with increased diabetes incidence especially when time spent on sedentary activities (such as watching television and sitting) was high and abdominal obesity was high. Shrivastava, Misra, Mohan, Unnikrishnan, and Bachani (2017) have found evidence that South Asians consumed more calories from carbohydrates and their foods had a greater glycemic index compared to their European counterparts. These dietary patterns have been linked to greater NCD risks. However, research in this area is new and needs to be further developed. In addition, given that it is a new phenomenon, interventions have not yet been incorporated into policy making.

Micronutrient deficiency (hidden hunger) is the third component of the triple burden that has been linked to lower diet diversity of households. At various points in the country's history, the nutrition department has run information campaigns on better diets and nutrition. A cross-sectional study on the effectiveness of advertisement campaigns on purchasing iodized salt found that it reduced undernutrition of children, but the authors found the effects to be very small (S. Kumar \& Berkman, 2015). In the 1990s, famous national advertising campaigns that encouraged the consumption of milk and eggs became a part of nutritional messaging in the country. Even though knowledge about the benefits of these products grew, there have been no experimental evaluations of the impact of these information and communication programs on household diet diversity or nutritional outcomes thus far. In the chapter on policy (11), we discuss the possibility of introducing laws for increasing food safety, fortification of foods and biofortification of crops as methods to improve access to micronutrients in food at the economy level and hence at the household level.

\subsubsection{Increasing Household Incomes}

When the level of income or the number of employment-generating opportunities that households have access to is low and the probability that households are impacted by productivity shocks is high, households faced greater 
income insecurity. By reducing the ability of households to plan ahead and thus purchase diverse foods from markets, income insecurity reduces the affordability of nutritious diets and thus increases malnutrition. In households from more developed states in India, greater income security (incomes per capita) and more market access (greater employment opportunities) have been found to be correlated with higher dietary diversity and lower levels of undernutrition (Koppmair, Kassie, \& Qaim, 2017; Sibhatu, Krishna, \& Qaim, 2015). Agricultural households from these areas too have greater incomegenerating capability and hence better access to nutritious foods and hence better nutrition outcomes. In lagging states in India, agricultural households are more likely to consume food from their own farms (P. Pingali, Mittra, \& Rahman, 2017). Research from other similar subsistence agriculture contexts has shown that access to home gardens or livestock related livelihood opportunities can improve diet diversity and nutrition in such contexts (Ali, Ahmed, \& Islam, 2008; Berti, Krasevec, \& FitzGerald, 2004; Jones, Shrinivas, \& Bezner-Kerr, 2014; Masset, Leroy, \& Frongillo, 2007).

Looking at effective interventions across the country, commercialization of the agricultural production system is an important pathway to increase ST, reduce rural poverty and reduce rural malnutrition. In order to enable greater commercialization, reducing transaction costs in participating supply chains (Abraham \& Pingali, 2017) as well as strengthening the participation of the retail sector in procurement and distribution of foods from small farms is an important way forward (Boselie, Henson, \& Weatherspoon, 2003; Reardon, Timmer, \& Minten, 2012; Thomas Reardon \& Minten, 2011). ${ }^{8}$ As seen in Chap. 3, non-farm incomes and remittances from migrants have also been found to play an important role in increasing income security and diet diversity as well as reducing malnutrition in rural households (Babatunde \& Qaim, 2010; Binswanger-Mkhize, 2012; Imai, Gaiha, \& Thapa, 2015; Owusu, Abdulai, \& Abdul-Rahman, 2011; Benjamin, Reardon, Stamoulis, \& Winters, 2002; Binswanger-Mkhize, 2013). Also, interventions that reduce costs of migrating, rural infrastructure projects that increase access to urban markets and rural development programs that stimulate local markets can thus alleviate malnutrition by increasing household incomes. In urban areas as well, income per capita, permanent employment opportunities and better-quality urban infrastructure are known to be correlated with greater diet diversity as well as lower undernutrition. However, there is very little research on the pathways that impact urban food (in)security (Maxwell, 1999). Moving forward, urbanization trends in

\footnotetext{
${ }^{8}$ This will be discussed in Chap. 8 .
} 
India will reconfigure the importance of urban food security in the nutrition debates. Developing interventions that focus on improving urban food security will become important as we look ahead.

The second pathway that reduces the affordability of nutritious diets and thus increases household-level malnutrition is unanticipated shocks to household productivity. In this regard, poor households are more likely to be impacted by unanticipated catastrophic events such as health, weather or food price shocks. This increases their vulnerability and thus impacts malnutrition. Research has shown that in the absence of appropriate financial tools to hedge against short-term production risks, crop price shocks tend to translate into worse malnutrition outcomes of households (Bellemare, 2015; De Brauw, 2011; Ivanic \& Martin, 2008; R. T. Jensen \& Miller, 2008). For example, in Nicaragua, undernutrition in children worsened when incomes of small farmer households growing coffee were hurt by price shocks from the international coffee markets (Maluccio, 2005). In other instances, weather-related shocks such as lower rainfall or longer droughts have been found to worsen nutrition outcomes of both children and adults. For example, famines caused by extended periods of drought have been linked to a reduction in the long-term productivity of adults who experienced these shocks when they were in utero. Providing adequate protection through crop or weather insurance is thus important towards ensuring that households are protected against lower nutrition outcomes. Health shocks can be devastating for household food security and nutritional outcomes (Strauss \& Thomas, 1998; R. M. Townsend, 1994, 1995; Asfaw \& Braun, 2004). Krishna (2011) has documented an unanticipated health shock to the breadwinner of the family can impoverish households. In the short term, health spending can increase household debt, thus reducing household access to nutritious foods. In the long run, the productivity of households can reduce if children are taken out of school to work or women have to participate in labor markets that pay them lower wages.

At the economy level, structural transformation and economic growth has led to changing preferences in diets and has increased opportunity costs of home food preparation (due to rising wages). These phenomena have been correlated with greater demand for eating diverse foods and eating more processed foods available at supermarkets and restaurants (Pingali, 2006; Popkin, 1999, 2003). ${ }^{9}$ These changes are reflected both in

\footnotetext{
${ }^{9}$ See Chap. 4 for discussion on patterns and factors of this phenomenon.
} 
the growth in expenditure shares in household spending on non-staples, such as milk, eggs and meat relative to staples, and in the greater demand for eating out (Gaiha, Jha, \& Kulkarni, 2013). While many of these dietary changes have been linked to lower undernutrition and hidden hunger outcomes, Anjana et al. (2015) found that increased intake of refined cereals, fruits and vegetables, dairy products, and monounsaturated fatty acid was correlated with increased diabetes when sedentary activities and abdominal obesity of individuals was also high. There is some evidence to show that greater income per capita has increased the consumption sugary and fat-based products (Gaiha et al., 2013; V. Gupta, Downs, Ghosh-Jerath, Lock, \& Singh, 2016; P. Pingali, 2006). Consumption of these types of foods has been associated with greater obesity incidence. Also, Arora et al. (2014) argue that doubling in the per capita consumption of these products over the last 15 years can be correlated with increases in obesity in the country. However obesity is still a new phenomenon in India. Hence there has been very little research done so far to understand the income effects of food demand on obesity in the country. Also thus far the obesity phenomenon is largely urban and is linked to higher incomes per capita, but research from developed country contexts finds that as the difference in incomes per capita increases, obesity incidence becomes a burden for poorer populations. In the absence of a food system that accounts for this issue of access, obesity becomes a major threat to future health systems.

\subsubsection{Pathways to Reduce Individual Malnutrition by Improving Access}

Across India and in all types of malnutrition indicators, women and children do far worse than the adult males. Within the same household as well, it is common to see that women, children or older-age adults are more malnourished than the adult male or breadwinner. Even between children, boys are known to have better nutrition outcomes than girls. There are two major explanations for the intra-household variation in malnutrition outcomes. First, observable traits such as gender, age, education and labor force participation often determine who has access to nutrition within households. Households tend to invest their scarce resources towards individuals who have the highest potential to improve household welfare. Even if not directly observed, intra-household dynamics such as bargaining power, time use patterns and cultural beliefs and practices can also create unanticipated trade-offs between household members and thus 
moderate their access to food and nutrition. Even in completely egalitarian and altruistic households, the health environment often plays a role in increasing morbidity and sickness. Combined with age, health stock of individuals and their access to food, a poor health environment creates barriers to nutrient absorption. Lack of water or sanitation facilities and high incidence of communicable diseases increase morbidity of children and hence reduce their ability to access nutrition. For older adults, age and susceptibility to NCDs also increases morbidity and hence affects their nutrition outcomes. These factors contribute to intra-household dynamics that result in nutrition outcomes that differ across individuals who live within the same household.

\subsubsection{Inducing Positive Nutrition Behaviors Within Households}

Within households, nutrition disparities are the outcome of six important channels. One, in many poor agricultural households, the low opportunity cost of time, reflected by low (agricultural) wages of women and girls relative to men and boys, creates a nutrition-productivity spiral in favor of the men and at the expense of women. This problem is particularly harsh in income-constrained households where members may allocate more market work to the higher-paid members, thus reinforcing a productivity nutrition trade-off in their favor (J. R. Behrman \& Deolalikar, 1993, 1990; Deolalikar, 1988). These trade-offs become salient when households experience income shocks. For example, nutritional outcomes of women and girl children worsen when there are agriculture-related shocks such as droughts or floods, during price shocks and during labor market shocks such as health shocks, migration-related shocks and economic downturns (Agüero \& Marks, 2011; Akresh, Verwimp, \& Bundervoet, 2011; Alderman et al., 2006; Baez \& Santos, 2007; D'Souza \& Jolliffe, 2013; del Ninno \& Lundberg, 2005; Ferreira \& Schady, 2009; J. Hoddinott, 2006; R. Jensen, 2000). Two, women are often relegated to household tasks such as water and firewood collection or threshing and harvesting on the fields. These tasks are energy intensive, but they are undervalued in the market (H. R. Barrett et al., 2005; Kadiyala, Harris, Headey, Yosef, \& Gillespie, 2014). Even though there is no strong evidence that malnutrition outcomes of children worsen when mothers go back to work, women maybe expected to stay home and involve themselves in child care (Bennett, 1988; Glick \& Sahn, 1998; Kes \& Swaminathan, 2006; Leslie, 1988). These services too are undervalued and thus women's (girls) household contributions tend to be undervalued in favor of men (boys) thus reducing access. 
Studies from Mexico have found that changing returns to household work through cash transfers for girl children can be one way to help reduce their time spent on household work and to keep them in schools (Parker \& Skoufias, 2000). Three, Jayachandran and Pande (2017) found the oldest male child within a household had better nutrition-related outcomes compared to similar children in Africa. However, any other child (with a higher birth order) fared worse than a comparable group of children from the same context. Hoddinott and Kinsey (2001) and Maccini and Yang (2009) also found that when there were rainfall shocks, within the same household, girls' malnutrition and schooling outcomes worsened in relation to boys' malnutrition outcomes. Thus discriminatory practices based on birth order of gender often lead to different nutrition outcomes between groups of children within the same households. Four, intra-household bargaining literature shows that when women have more bargaining power within households nutritional outcomes of all members improve. For example, when households are headed by women rather than men, the nutrition outcomes of children are better in the former even if their incomes were lower on average (Headey, 2013; C. Johnson \& Rogers, 1993). Multiple authors have found that women's education is a powerful channel through which household malnutrition, as well as intergenerational health outcomes of children, can improve (Case \& Ardington, 2006; Currie \& Moretti, 2003; Oreopoulos, Page, \& Stevens, 2006; Thomas, Strauss, \& Henriques, 1991). Intra-household bargaining power of women is also reflected in the amount of freedom they have to control resources when they belong to male-dominated households. Multiple researchers have found that increase in empowerment of women within households, represented by greater financial control and more physical mobility outside the home, played an important role in improving child nutrition indicators (Imai, Annim, Kulkarni, \& Gaiha, 2014; Shroff, Griffiths, Adair, Suchindran, \& Bentley, 2009; M. R. Shroff et al., 2011). Thus increasing women's education, bargaining power and empowering women to take decisions within households will be important towards decreasing intrahousehold disparities. Five, within households, it can also be the case that households may not have proper information on nutritional behaviors that can impact malnutrition. In sub-Saharan Africa, evaluations of behavior change communication programs on breastfeeding have been found to be effective in increasing knowledge, duration of breastfeeding and health outcomes especially for babies whose mothers are HIV positive (Coovadia et al., 2007; Thior et al., 2006). Interventions such as the distribution of vitamin A and iron tablets in India have been unsuccessful in reducing 
micronutrient deficiency since households lack information on the benefits of following treatment protocols properly. Six, cultural practices often prevent women and children from accessing the necessary care from interventions that are focused on improving their health. In some cases, cultural beliefs about the micronutrients' effects on health play a role in reducing whether women and children continue treatment. For example, in India, Nichter (2008) found that women were discouraged to take iron supplements since midwives from the villages believed it would increase the size of the baby in utero and thus increase complications for child mortality in women who were giving birth. However, the flip side to the argument was that women who were anemic were highly susceptible to maternal mortality risks. Changing these behaviors require education interventions for all household members, informational campaigns about the importance of nutrition and economic growth policies that are inclusive.

Programs such as the ICDS focus on addressing malnutrition by providing pregnant women and new mothers with reproductive healthcare such as ante-natal checkups, nutrition supplements such as iron tablets, nutritious meals and information on managing nutrition intake during their pregnancies. For newborn children, the ICDS provides post-natal care, monitors anthropometric health of newborn children and educate mothers on the importance of breastfeeding and eating healthy. Information on nutrition supplements and nutrition intake for children are also provided to new mothers with the view to change behavior. Evaluations of these programs have found that iron-related nutrition outcomes of children improved after women were educated on the same (Kapur, Sharma, \& Agarwal, 2003). With regard to undernutrition, additional interventions such as encouraging early initiation of breastfeeding practices were found to be more effective than just providing individuals with more information on nutrition practices (Kumar, Goel, Mittal, \& Misra, 2006). Introduction of complementary feeding practices along with breastfeeding was found to be associated with better nutrition outcomes for children in some areas as well (Menon, Bamezai, Subandoro, Ayoya, \& Aguayo, 2015). In states such as Maharashtra, regular monitoring of babies and mothers and strict protocols to identify and treat groups that are at high risk of malnutrition have played an important role in reducing its severity. Greater citizen involvement has also been thought to be the key motivation for creating efficient systems in Maharashtra. The MDMS program, on the other hand, has been found to be an extremely cost-effective program in improving nutrition outcomes of students. Afridi (2010) found that for less than Rs. 20 a day, 
a child attending a school with access to MDMS reduced their daily dietary calorie deficiency by $30 \%$, iron deficiency by $10 \%$ and reduced protein deficiency by $100 \%$.

India has some of the world's worst rates of anemia for men, women and children, and this burden exists across states and economic development outcomes in the country. Anemia has been linked to the lack of micronutrient availability in diets and is known to have many long-term negative health effects on individuals as well. Many interventions implemented by the health department in India have focused on improving the last mile access with regard to micronutrients. For example, distribution of vitamin $\mathrm{A}$ and iron capsules for pregnant women and babies have long been part of the strategy to improve reproductive and child health in the country. However, there have not been many rigorous evaluations of these programs. For example, Semba et al. (2010) found some evidence that vitamin A interventions in India did reduce child undernutrition, especially wasting in children. However, the effects were modest at best. In cases where it has worked, experts have shown that there are significant improvements to child health. Adhvaryu and Nyshadham (2016) found that when children were exposed to iodine supplementations in utero, they were more like to have better health and cognitive outcomes compared to a sibling who was not exposed.

The other important and growing phenomenon in the malnutrition burden is obesity incidence. A systematic review of the nature of obesity within households reveals that in less developed countries, obesity is an outcome of income and is equally prevalent between men and women in rich households. However, greater economic development becomes associated with obesity of women in the lower income strata, but male obesity tended to more malleable to economic growth (Dinsa, Goryakin, Fumagalli, \& Suhrcke, 2012). In these contexts, obesity of women is also associated with a higher premium in labor markets regarding reduced wages as well as greater health spending (Cawley, 2004, 2010). These effects are known to spill over on poor health outcomes that have negative effects for both women and their children. In India, S. Gulati et al. (2013) find that socio-economic indicators and the lack of knowledge on obesity explain the high overweight rates of girls and boys in urban schools. However, other than the income and information pathways, there is very little known about why women and children may be susceptible to obesity in the country. Given its challenges for health, this becomes an extremely crucial investment area as we think ahead to improve nutrition outcomes. 


\subsubsection{Improving Nutrient Absorption by Investing in the Health Environment}

Poor nutrition and a poor health environment have an endogenous relationship. Among the factors that increase this vulnerability are the age of the individual and their health stock. Children who are undernourished or anemic, for example, are more susceptible to diseases in the health environment (Horton \& Ross, 2003; Thakur, Chandra, Pemde, \& Singh, 2014). Similarly, children who have higher morbidity have worse malnutrition outcomes (Clasen et al., 2014; Miguel \& Kremer, 2015). This endogeneity reinforces the problem of poor nutrient absorption for children. A poor health environment can be an outcome of low quality of drinking water, inadequate sewerage facilities, proximity to fecal contamination by livestock and humans and poor hygiene in water and sanitation practices. As disease burden increases in the surrounding areas, constant exposure to disease reduces individuals' ability to absorb nutrition from foods that they eat.

In India, much of the disease burden still comes from diarrhea incidence. Diarrhea is an outcome of bacterial and viral infections that can be transmitted through an unclean environment. In Fig. 5.12, we see the strong correlation between low sanitation infrastructure and diarrhea incidence in children. Hammer and Spears (2016) and Spears, Ghosh,

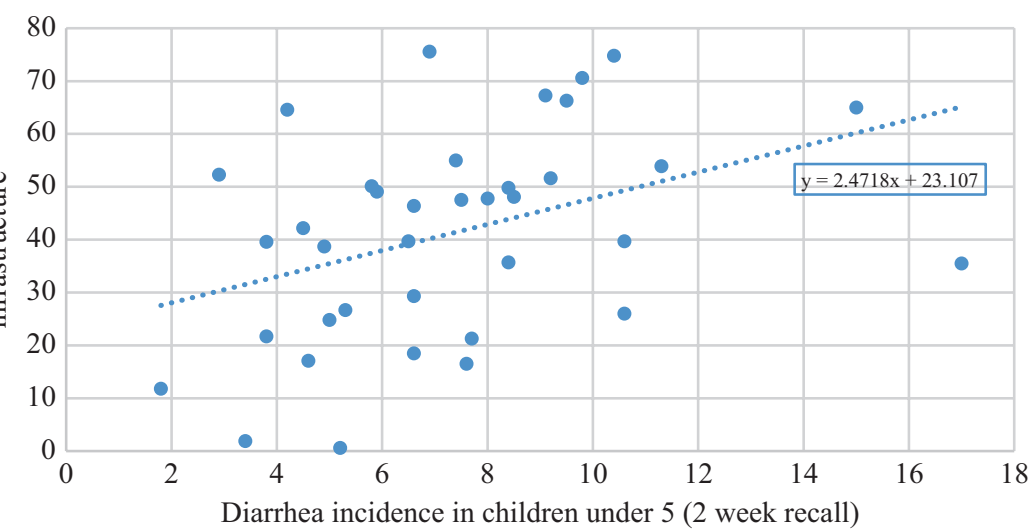

Fig. 5.12 Relationship between diarrhea prevalence and lack of sanitation. Source: NFHS 2015-16; based on authors calculations 
and Cumming (2013) showed that in India, reduction in stunting was correlated with a reduction in open defecation in villages through the construction of toilet infrastructure. In the lagging states of Madhya Pradesh and Orissa, Clasen et al. (2014) and Patil et al. (2014) showed that constructing toilets could not help reduce diarrheal infections since households did not engage in clean sanitation behaviors even after the infrastructure became available. Supplementing investments made in constructing infrastructure for water and sanitation services, along with BCC interventions, has been found to be most effective in improving nutrition in many other developing countries. Having access to clean water and engaging in hygienic practices for sanitation-related cleanliness was found to be effective in lowering disease burden and hence improving nutrition outcomes in India (Lee, Rosenzweig, \& Pitt, 1997; Mangyo, 2008). Rah et al. (2015) found that in areas where the primary care givers encouraged clean drinking water practices such as washing hands before eating and after using the toilet, stunting-related malnutrition decreased. In places where households consume water stored in containers, sanitizing water storage facilities through the addition of chlorine tablets has been found to decrease the spread of disease (Mengistie, Berhane, \& Worku, 2013). Other practices such as boiling water before consuming it and encouraging people to wash hands with soap before they eat has been found to be effective in the fight against diarrhea (Biran et al., 2008). Other health-related interventions such as vaccinations against communicable diseases, distribution of deworming tablets, provision of bed nets to reduce the spread of mosquitoes and malaria have also been found to be effective in improving child health (Lim et al., 2011; Miguel \& Kremer, 2015). By reducing morbidity, these interventions improve the nutrition absorption capacity of children and thus can contribute to the fight against malnutrition.

\subsection{Challenges for the Future}

Moving the country from high undernutrition to low undernutrition while simultaneously preventing an increase in obesity needs to be a key goal for enabling a smooth transition towards better health. However tackling high undernutrition, micronutrient deficiency or high prevalence of obesity requires different interventions that address key challenges based on the malnutrition type. In Fig. 5.13, we see that obesity has become a problem of high incomes, while undernutrition is correlated 

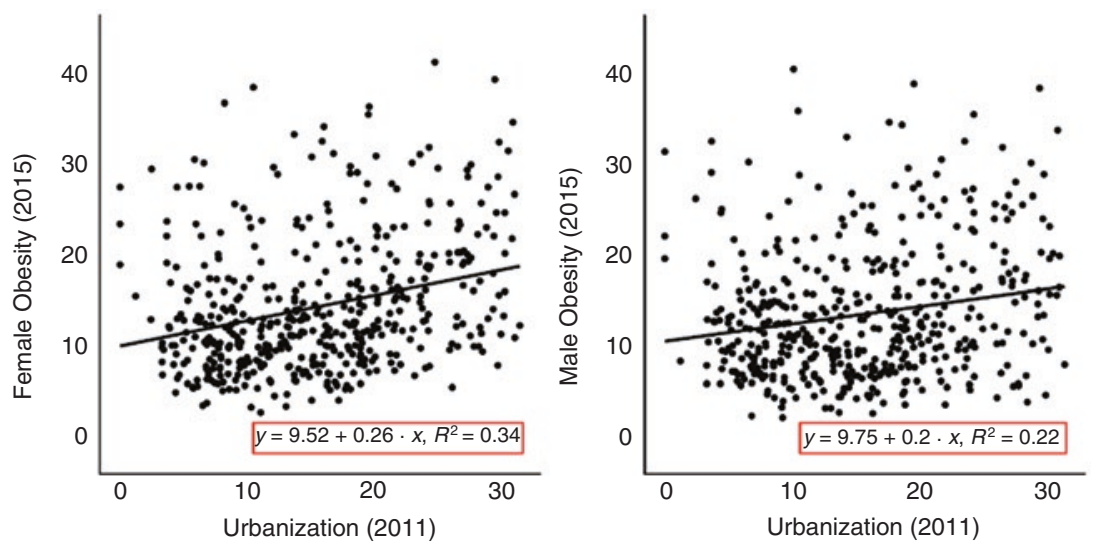

Fig. 5.13 District-level association between urbanization and obesity. Source: Census 2011 and NFHS 2015-16; based on authors calculations

with low ST. Hence interventions need to address the specific nutritioneconomic growth context of ST that aligns with each state. For example, tackling obesity in urbanizing states like Kerala would need to become the key focus of state development policies while tackling undernutrition in lagging states like UP needs to remain a priority. Within each of these categories, identifying the main channel through which malnutrition is impacted should be identified both by state and by district. For example, in more hilly areas of Chhattisgarh, solving the problem of access to food maybe more important for reducing undernutrition while improving sanitation access might be more effective in the plains of Madhya Pradesh. Similarly, improving nutrition education and positive nutrition behaviors might be key in Tamil Nadu where white collar jobs dominate economic growth while improving food grades and safety in Maharashtra would improve access to nutrition in urban areas, where much of food is accessed by eating out. Thus, looking ahead there is a need for more state specific research for identifying the most important pathway through which the threat for malnutrition can be reduced.

There are three additional challenges for the triple burden of malnutrition as we look ahead to 2050 . The first challenge is tackling the rising incidence of NCDs. As per the report (MoHFW, 2017), nearly $62 \%$ of all deaths in the country are due to NCDs. This number has nearly doubled 
in the last two decades. Urbanized states have the highest DALYs ${ }^{10}$ from premature deaths while lagging states have the lowest this far. NCDs account for $35 \%$ of premature deaths of individuals between the ages of 15 and 39 and $74 \%$ of all deaths for individuals between the ages of 40 and 69 in the country. Among the NCDs, cardiovascular diseases, chronic respiratory diseases, cancers and diabetes explain more than $80 \%$ of all deaths. DALYs from diabetes incidence has increased by $80 \%$ and unhealthy diets, higher blood pressure, high cholesterol and overweight now account for $25 \%$ of risk associated with NCDs. ${ }^{11}$ Urbanized states have seen the greatest increase in NCDs and also have the highest increases in obesity incidence (MoHFW, 2017). Given demographic projections for the future, increasing trends for urbanization and increasing incidence of obesity, there is a credible threat that NCDs will become a liability for health systems as well look ahead. This will not only impact malnutrition outcomes; it will lead to a reduction in the productivity of individuals as well as lower economic growth outcomes in the long run.

The second major threat comes from climate change. Changing rainfall patterns, an increase in the number of heat days and increased air and water pollution will worsen the health environment. By reducing access to essential resources such as water and increasing disease burden, climate change will increase the risks for malnutrition. Current research has shown that air and water pollution too can directly impact the health environment and thus health and mortality. Climatic risk factors will also directly impact the rate of incidence of NCDs and hence pose a further threat to progress made towards improving health (Kjellstrom, Holmer, \& Lemke, 2009; Majra \& Gur, 2009; Myers et al., 2017; Patz, Campbell-Lendrum, Holloway, \& Foley, 2005; Watts et al., 2015). Through the agricultural system, climate change also threatens to impact nutrition by reducing food availability and nutrient content in crops. Literature has suggested that women and children will be more vulnerable as climate change threatens access to water and other natural resources which occupy Cooperative Marketing Federation (much of the time use patterns for these groups. All these factors will further reduce the effectiveness of interventions currently designed to address malnutrition.

${ }^{10}$ DALYS - Disability Adjusted Life Years-years of healthy life lost due to premature death and suffering. DALYS = years of life lost + years lived with disability.

${ }^{11}$ The latter has increased from $10 \%$ in the 1990 s. 
The third challenge is the problem of growing income inequality across geographical space and incomes. The malnutrition transformation predicts that as incomes increase, undernutrition first decreases and is followed by an increase in over-nutrition. However, with higher levels of development, greater income inequality leads to over-nutrition incidence transitioning away from the rich towards a problem of the poor and less privileged. This transition is driven by increased access to unhealthy processed foods from supermarkets, higher opportunity costs related to home meal preparation as well as greater demand for diet diversity. In India, we are in the process of moving towards high over-nutrition even before we have successfully tackled the problem of undernutrition. This transition can be explained by both the growing income inequality within the country as well as the limited success of current interventions to tackle the undernutrition problem. Given that some states will progress more quickly towards completing their ST, guiding their economies away from a malnutrition transition through appropriate policy interventions that are best suited to the development experiences of the states will be important as we look ahead.

\subsection{Conclusion}

Similar to the experience of other countries that have undergone a greater structural transformation, India has made progress towards reducing hunger and reducing undernutrition as it emerges into the global stage. Over the last three decades, the country has managed to reduce undernutrition by at least ten percentage points across all individuals. However, tackling micronutrient deficiency continues to remain a challenge for policy makers. Anemia rates of children and women have remained stubbornly high and are still comparable to those in sub-Saharan African countries, which themselves have been on a lower transformation pathway. Much of the progress made towards tackling this problem has now been marred by the fast increasing rates of overweight individuals. This new phenomenon has blindsided policy efforts. While one may be tempted to argue that increasing obesity may itself represent the role of fast rising incomes (as experienced by many other countries), its rate of increase and its indirect effects on non-communicable diseases are extremely concerning. NCDs currently explain around $62 \%$ of all deaths in India, a doubling of the rate since the early 2000s. Much of the increase in NCDs has come from diseases such as heart conditions and diabetes which are closely related to issues of food access and malnutrition. This abrupt shift in the distribution of the triple 
burden of malnutrition is unprecedented, and experts and policy makers have become concerned about its impacts for the health of individuals both in the short term and the long term. In the short term, malnutrition has been found to lower labor productivity and reduce household food security. In the long term, growing numbers of unhealthy populations place a large public health burden on the Indian health system to deliver health services. This may affect the potential for long-term economic development.

Through this chapter, we provide an account of the pathways through which malnutrition can be reduced. We identify four such pathways using a food systems approach. At the household level, access to diverse diets and income security play a major role with regard to increasing food security and reducing malnutrition. Research has shown that helping households diversify their diets by increasing access to diverse foods through markets as well as increasing income and livelihood opportunities is important for tackling malnutrition. For obesity reduction as well, having access to nutritious diets, reducing overconsumption of calories from sugar as well as increasing income security, will play an important role. Within the household, intra-household dynamics with regards to food access and the quality of the surrounding health environment determine an individual's ability to absorb nutrition from food. Women and children in households are thus especially vulnerable to malnutrition compared to men. Research from developed country contexts suggests that these dynamics play out obesity risks as well. Higher obesity has been found to be associated with poor economic outcomes and lower intergenerational health for women. Spillovers from increasing obesity rates often impact incidence and mortality related to NCDs as well. Thus, improving welfare in the future involves a continued commitment towards the reduction of undernutrition and micronutrient deficiencies, as well as increasing commitment towards reducing risk factors for obesity and thus NCDs.

In this chapter, we present evidence on the success of various interventions that have been implemented in India to tackle the issue of malnutrition. Our chapter also highlights areas where more research or evidence is required to understand how malnutrition can be reduced. For example, we show that there is very little known on the pathways through which obesity can be reduced. Similarly, though there have been many interventions to reduce hidden hunger or micronutrient deficiencies, there is little known on what has worked or not. Also, we discuss the importance of investing in other channels for reducing undernutrition such as reducing 
communicable disease incidence through vaccinations and increasing access to clean and safe drinking water. We also highlight the differences in the national and regional policy responses to the nutrition issue and argue that a decentralized approach is now more relevant in tackling malnutrition. For example, we propose that discussions on reducing obesity need to become more important in the food policy debates in urbanizing states, while their agricultural policies need to focus on increasing rural income security. In lagging states on the other hand, food and agricultural policy needs to remain focused on reducing undernutrition and hidden hunger. In addition, we highlight the risks that climate change, rising NCDs and regional inequality pose to tackling malnutrition. These phenomena, we argue, increase health systems risks associated with malnutrition and will derail progress made towards achieving better health if not addressed. Thus achieving the goal for nutrition security for the future will require interventions that simultaneously tackle the multiple challenges that impact the triple burden of malnutrition.

\section{REFERENCES}

Abraham, M., \& Pingali, P. (2017). Transforming smallholder agriculture to achieve the SDGs. In L. Riesgo, S. Gomez-Y-Paloma, \& K. Louhichi (Eds.), The role of small farms in food and nutrition security. Springer.

Adhvaryu, A., \& Nyshadham, A. (2016). Endowments at birth and parents' investments in children. The Economic Journal, 126(593), 781-820.

Afridi, F. (2010). Child welfare programs and child nutrition: Evidence from a mandated school meal program in India. Journal of Development Economics, 92(2), 152-165. https://doi.org/10.1016/j.jdeveco.2009.02.002

Agüero, J. M., \& Marks, M. S. (2011). Motherhood and female labor supply in the developing world: Evidence from infertility shocks. Journal of Human Resources, 46(4), 800-826. https://doi.org/10.1353/jhr.2011.0002

Akhtar, S., Ahmed, A., Randhawa, M. A., Atukorala, S., Arlappa, N., Ismail, T., \& Ali, Z. (2013). Prevalence of vitamin A deficiency in South Asia: Causes, outcomes, and possible remedies. Journal of Health, Population, and Nutrition, 31(4), 413-423. Retrieved from http://www.ncbi.nlm.nih.gov/pmc/articles/PMC3905635/

Akresh, R., Verwimp, P., \& Bundervoet, T. (2011). Civil war, crop failure, and child stunting in Rwanda. Economic Development and Cultural Change, 59(4), 777-810. https://doi.org/10.1086/660003

Akresh, R., Verwimp, P., \& Bundervoet, T. (2013). Civil war, crop failure, and child stunting in Rwanda. Economic Development and Cultural Change, $59(4), 777-810$. 
Alaimo, K., Olson, C. M., \& Frongillo, E. A., Jr. (2001). Low family income and food insufficiency in relation to overweight in US children: Is there a paradox? Archives of Pediatrics and Adolescent Medicine, 155(10), 1161-1167. https:// doi.org/10.1001/archpedi.155.10.1161

Alderman, H., Hoddinott, J., \& Kinsey, B. (2006). Long term consequences of early childhood malnutrition. Oxford Economic Papers, 58(3), 450-474. https://doi.org/10.1093/oep/gpl008

Ali, M. Y., Ahmed, M. M., \& Islam, M. B. (2008, April). Homestead vegetable gardening: Meeting the need of year round vegetable requirement of farm family. In National Workshop on Multiple Cropping held at Bangladesh Agricultural Research Council, Farmgate, Dhaka, Bangladesh, pp. 23-24.

Allen, L. H., Peerson, J. M., \& Olney, D. K. (2009). Provision of multiple rather than two or fewer micronutrients more effectively improves growth and other outcomes in micronutrient-deficient children and adults. The Journal of Nutrition, 139(5), 1022-1030. https://doi.org/10.3945/jn.107.086199

Almond, D., \& Currie, J. (2011). Killing me softly: The fetal origins hypothesis. Journal of Economic Perspectives, 25(3), 153-172. https://doi.org/10.1016/j. surg.2006.10.010.Use

Anjana, R. M., Sudha, V., Nair, D. H., Lakshmipriya, N., Deepa, M., Pradeepa, R., ... Mohan, V. (2015). Diabetes in Asian Indians-How much is preventable? Ten-year follow-up of the Chennai Urban Rural Epidemiology Study (CURES-142). Diabetes Research and Clinical Practice, 109(2), 253-261. https://doi.org/10.1016/j.diabres.2015.05.039

Arimond, M., \& Ruel, M. T. (2004). Dietary diversity is associated with child nutritional status: Evidence from 11 demographic and health surveys. The Journal of Nutrition, 134(July), 2579-2585.

Arora, N. K., Pillai, R., Dasgupta, R., \& Garg, P. R. (2014). Whole-of-society monitoring framework for sugar, salt, and fat consumption and noncommunicable diseases in India. Annals of the New York Academy of Sciences, 1331(1), 157-173. https://doi.org/10.1111/nyas.12555

Asfaw, A., \& Braun, J. v. (2004). Is consumption insured against illness? Evidence on vulnerability of households to health shocks in rural Ethiopia. Economic Development and Cultural Change, 53(1), 115-129.

Azadbakht, L., \& Esmaillzadeh, A. (2011). Dietary diversity score is related to obesity and abdominal adiposity among Iranian female youth. Public Health Nutrition, 14(1), 62-69.

Babatunde, R. O., \& Qaim, M. (2010). Impact of off-farm income on food security and nutrition in Nigeria. Food Policy, 35(4), 303-311. https://doi. org/10.1016/j.foodpol.2010.01.006

Baez, J. E., \& Santos, I. V. (2007). Children's vulnerability to weather shocks: A natural disaster as a natural experiment. Syracuse University, Mimeo. 
Barrett, H. R., Browne, A. W., Hyder, A. A., Maman, S., Nyoni, J. E., Khasiani, S. A., ... Sohani, S. (2005). The pervasive triad of food security, gender inequity and women's health: Exploratory research from sub-Saharan Africa. Community Development Journal, 29(3), 203-214.

Behrman, J. R., \& Deolalikar, A. B. (1990). The intrahousehold demand for nutrients in rural South India individual estimates, fixed effects, and permanent income. The Journal of Human Resources, 25(4), 665-696.

Behrman, J. R., \& Deolalikar, A. B. (1993). The intrahousehold distribution of market labour supply in rural South India. Oxford Bulletin of Economics and Statistics, 55(4), 409-421.

Bellemare, M. F. (2015). Rising food prices, food price volatility, and social unrest. American Journal of Agricultural Economics, 97(1), 1-21. https://doi. org/10.1093/ajae/aau038

Benjamin, D., Reardon, T., Stamoulis, K. G., \& Winters, P. (2002). Promoting farm/non-farm linkages for rural development-Case studies from Africa \& Latin America. Rome: FAO.

Bennett, L. (1988). The role of women in income production and intra-household allocation of resources as a determinant of child nutrition and health. Food and Nutrition Bulletin, 10(3), 16-26.

Berti, P. R., Krasevec, J., \& FitzGerald, S. (2004). A review of the effectiveness of agriculture interventions in improving nutrition outcomes. Public Health Nutrition, 7(5), 599-609. https://doi.org/10.1079/PHN2003595

Binswanger-Mkhize, H. P. (2012). India 1960-2010: Structural change, the rural non-farm sector, and the prospects for agriculture. In Center on Food Security and the Environment Stanford Symposium Series on Global Food Policy and Food Security in the 21st Century, Stanford University. Citeseer.

Binswanger-Mkhize, H. P. (2013). The stunted structural transformation of the Indian economy: Agriculture, manufacturing and the rural non-farm sector. Economic and Political Weekly, 48, 5-13. Retrieved from https://www.epw. in/journal/2013/26-27/review-rural-affairs-review-issues/stuntedstructuraltransformation-indian

Biran, A., Rabie, T., Schmidt, W., Juvekar, S., Hirve, S., \& Curtis, V. (2008). Comparing the performance of indicators of hand-washing practices in rural Indian households. Tropical Medicine \& International Health, 13(2), 278-285.

Black, R. E., Victora, C. G., Walker, S. P., Bhutta, Z. A., Christian, P., de Onis, M., ... Uauy, R. (2013). Maternal and child undernutrition and overweight in lowincome and middle-income countries. The Lancet, 382(9890), 427-451. https://doi.org/10.1016/S0140-6736(13)60937-X

Bobonis, G. J., Miguel, E., \& Sharma, C. P. (2004). Iron deficiency anemia and school participation. Poverty Action Lab Paper (No. 7), pp. 1118-1120.

Boselie, D., Henson, S., \& Weatherspoon, D. (2003). Supermarket procurement practices in developing countries: Redefining the roles of the public and private sectors. American Journal of Agricultural Economics, 85(5), 1155-1161. 
Brabin, B. J., Hakimi, M., \& Pelletier, D. (2001). An analysis of anemia and pregnancy-related maternal mortality. The Journal of Nutrition, 131(2), 604S-615S.

Busert, L. K., Neuman, M., Rehfuess, E. A., Dulal, S., Harthan, J., Chaube, S. S., ... Manandhar, D.S. (2016). Dietary diversity is positively associated with deviation from expected height in rural Nepal-3. The Journal of Nutrition, 146(7), 1387-1393.

Case, A., \& Ardington, C. (2006). The impact of parental death on school outcomes: Longitudinal evidence from South Africa. Demography, 43(3), 401-420.

Cawley, J. (2004). The impact of obesity on wages. The Journal of Human Resources, 39(2), 451. https://doi.org/10.2307/3559022

Cawley, J. (2010). The economics of childhood obesity. Health Affairs, 29(3), 364-371. https://doi.org/10.1377/hlthaff.2009.0721

Cawley, J. (2015). An economy of scales: A selective review of obesity's economic causes, consequences, and solutions. Journal of Health Economics, 43, 244-268. https://doi.org/10.1016/j.jhealeco.2015.03.001

Chen, Y., \& Zhou, L.-A. (2007). The long-term health and economic consequences of the 1959-1961 famine in China. Journal of Health Economics, 26(4), 659-681.

Clasen, T., Boisson, S., Routray, P., Torondel, B., Bell, M., Cumming, O., ... Schmidt, W. P. (2014). Effectiveness of a rural sanitation programme on diarrhoea, soil-transmitted helminth infection, and child malnutrition in Odisha, India: A cluster-randomised trial. The Lancet Global Health, 2(11), e645-e653. https://doi.org/10.1016/S2214-109X(14)70307-9

Coovadia, H. M., Rollins, N. C., Bland, R. M., Little, K., Coutsoudis, A., Bennish, M. L., \& Newell, M.-L. (2007). Mother-to-child transmission of HIV-1 infection during exclusive breastfeeding in the first 6 months of life: An intervention cohort study. The Lancet, 369(9567), 1107-1116.

Currie, J., \& Moretti, E. (2003). Mother's education and the intergenerational transmission of human capital: Evidence from college openings. The Quarterly Journal of Economics, 118(4), 1495-1532.

D'Souza, A., \& Jolliffe, D. (2013). Conflict, food price shocks, and food insecurity: The experience of Afghan households. Food Policy, 42, 32-47. https:// doi.org/10.1016/j.foodpol.2013.06.007

De Brauw, A. (2011). Migration and child development during the food price crisis in El Salvador. Food Policy, 36(1), 28-40. https://doi.org/10.1016/j. foodpol.2010.11.002

Deaton, A. (1987). Estimation of own- and cross-price elasticities from household survey data. Journal of Econometrics, 36(1-2), 7-30.

del Ninno, C., \& Lundberg, M. (2005). Treading water. The long-term impact of the 1998 flood on nutrition in Bangladesh. Economics and Human Biology, 3(1), 67-96. https://doi.org/10.1016/j.ehb.2004.12.002 
Deolalikar, A. B. (1988). Nutrition and labor productivity in agriculture: Estimates for rural South India. The Review of Economics and Statistics, 70(3), 406-413.

Dinsa, G. D., Goryakin, Y., Fumagalli, E., \& Suhrcke, M. (2012). Obesity and socioeconomic status in developing countries: A systematic review. Obesity Reviews, 13(11), 1067-1079. https://doi.org/10.1111/j.1467-789X.2012. 01017.x

Dubowitz, T., Levinson, D., Peterman, J. N., Verma, G., Jacob, S., \& Schultink, W. (2007). Intensifying efforts to reduce child malnutrition in India: An evaluation of the Dular program in Jharkhand, India. Food and Nutrition Bulletin, $28(3), 266-273$.

Ferreira, F. H. G., \& Schady, N. (2009). Aggregate economic shocks, child schooling, and child health. The World Bank Research Observer, 24(2), 147-181. https://doi.org/10.1093/wbro/lkp006

Gaiha, R., Jha, R., \& Kulkarni, V. S. (2013). How pervasive is eating out in India? Journal of Asian and African Studies, 48(3), 370-386. https://doi. org/10.1177/0021909612472040

Glick, P., \& Sahn, D. E. (1998). Maternal labour supply and child nutrition in West Africa. Oxford Bulletin of Economics and Statistics, 60(3), 325-355.

Gørgens, T. (2002). Selection and stunting effects of famine: A case study of the Great Chinese Famine.

Gørgens, T., Meng, X., \& Vaithianathan, R. (2012). Stunting and selection effects of famine: A case study of the Great Chinese Famine. Journal of Development Economics, 97(1), 99-111. https://doi.org/10.1016/j.jdeveco.2010.12.005

Griffiths, P. L., \& Bentley, M. E. (2001). The nutrition transition is underway in India. The Journal of Nutrition, 131(10), 2692-2700. http://doi. org/0022-3166/01

Gulati, S., Misra, A., Colles, S. L., Kondal, D., Gupta, N., Goel, K., .. Bhardwaj, S. (2013). Dietary intakes and familial correlates of overweight/obesity: A four-cities study in India. Annals of Nutrition and Metabolism, 62(4), 279-290. https://doi.org/10.1159/000346554

Gupta, V., Downs, S. M., Ghosh-Jerath, S., Lock, K., \& Singh, A. (2016). Unhealthy fat in street and snack foods in low-socioeconomic settings in India: A case study of the food environments of rural villages and an urban slum. Journal of Nutrition Education and Behavior, 48(4), 269-279.el. https://doi. org/10.1016/j.jneb.2015.11.006

Gutierrez, F. H. (2013). Long-term consequences of early life health shocks: Evidence from the 1980s Peruvian crisis.

Hammer, J., \& Spears, D. (2016). Village sanitation and child health: Effects and external validity in a randomized field experiment in rural India. Journal of Health Economics, 48, 135-148. https://doi.org/10.1016/j.jhealeco.2016. 03.003 
Headey, D. D. (2013). Developmental drivers of nutritional change: A crosscountry analysis. World Development, 42(1), 76-88. https://doi.org/10.1016/ j.worlddev.2012.07.002

Hoddinott, J. (2006). Shocks and their consequences across and within households in Rural Zimbabwe. Journal of Development Studies, 42(2), 201-321.

Hoddinott, J., \& Kinsey, B. (2001). Child growth in the time of drought. Oxford Bulletin of Economics and Statistics, 63(4), 409-436. https://doi. org/10.1111/1468-0084.t01-1-00227

Hoddinott, J., Maluccio, J. A., Behrman, J. R., Flores, R., \& Martorell, R. (2008). Effect of a nutrition intervention during early childhood on economic productivity in Guatemalan adults. The Lancet, 371(9610), 411-416. https://doi. org/10.1016/S0140-6736(08)60205-6

Hoddinott, J., \& Yohannes, Y. (2002). Dietary diversity as a food security indicator. Discussion Paper (No. 136), International Food Policy Research Institute (IFPRI), Food Consumption and Nutrition Division, Washington, DC.

Horton, S., \& Ross, J. (2003). The economics of iron deficiency. Food Policy, 28(1), 51-75.

Imai, K. S., Annim, S. K., Kulkarni, V. S., \& Gaiha, R. (2014). Women's empowerment and prevalence of stunted and underweight children in rural India. World Development, 62, 88-105.

Imai, K. S., Gaiha, R., \& Thapa, G. (2015). Does non-farm sector employment reduce rural poverty and vulnerability? Evidence from Vietnam and India. Journal of Asian Economics, 36, 47-61. https://doi.org/10.1016/j. asieco.2015.01.001

Ivanic, M., \& Martin, W. (2008). Implications of higher global food prices for poverty in low-income countries. Agricultural Economics, 39, 405-416. https://doi.org/10.1111/j.1574-0862.2008.00347.x

Jayachandran, S., \& Pande, R. (2017). Why are Indian children so short? The role of birth order and son preference. American Economic Review, 107(9), $2600-2629$.

Jensen, R. (2000). Agricultural volatility and investments in children. American Economic Review, 90(2), 399-404. https://doi.org/10.1257/aer.90.2.399

Jensen, R. T., \& Miller, N. H. (2008). The impact of food price increases on caloric intake in China. Agricultural Economics, 39(1), 465-476. https://doi. org/10.1111/j.1574-0862.2008.00352.x

Jha, R., Gaiha, R., \& Sharma, A. (2009). Calorie and micronutrient deprivation and poverty nutrition traps in rural India. World Development, 37(5), 982-991. https://doi.org/10.1016/j.worlddev.2008.09.008

Johnson, C., \& Rogers, B. L. (1993). Children's nutritional female-headed households in the Dominican Republic. Social Science \& Medicine, 37(11), 1293-1301.

Jones, A. D., Hayter, A. K. M., Baker, C. P., Prabhakaran, P., Gupta, V., Kulkarni, B., ... Kumar, P. U. (2016). The co-occurrence of anemia and cardiometabolic 
disease risk demonstrates sex-specific sociodemographic patterning in an urbanizing rural region of southern India. European Journal of Clinical Nutrition, $70(3), 364-372$.

Jones, A. D., Shrinivas, A., \& Bezner-Kerr, R. (2014). Farm production diversity is associated with greater household dietary diversity in Malawi: Findings from nationally representative data. Food Policy, 46, 1-12.

Kadiyala, S., Harris, J., Headey, D., Yosef, S., \& Gillespie, S. (2014). Agriculture and nutrition in India: Mapping evidence to pathways. Annals of the New York Academy of Sciences, 1331(1), 43-56. https://doi.org/10.1111/nyas.12477

Kapur, D., Sharma, S., \& Agarwal, K. N. (2003). Effectiveness of nutrition education, iron supplementation or both on iron status in children. Indian Pediatrics, $40(12), 1131-1144$.

Kaushal, N., \& Muchomba, F. M. (2015). How consumer price subsidies affect nutrition. World Development, 74, 25-42. https://doi.org/10.1016/j. worlddev.2015.04.006

Kennedy, G., Ballard, T., \& Dop, M. C. (2011). Guidelines for measuring household and individual dietary diversity. FAO.

Kes, A., \& Swaminathan, H. (2006). Gender and time poverty in sub-Saharan Africa. In Gender, time use, and poverty in Sub-Saharan Africa (pp. 13-38). World Bank.

Kishore, A., \& Chakrabarti, S. (2015). Is more inclusive more effective? The 'New Style' public distribution system in India. Food Policy, 55, 117-130. https:// doi.org/10.1016/j.foodpol.2015.06.006

Kjellstrom, T., Holmer, I., \& Lemke, B. (2009). Workplace heat stress, health and productivity-An increasing challenge for low and middle-income countries during climate change. Global Health Action, 2(1), 2047.

Koppmair, S., Kassie, M., \& Qaim, M. (2017). Farm production, market access and dietary diversity in Malawi. Public Health Nutrition, 20(2), 325-335.

Krishna, A. (2011). One illness away: Why people become poor and how they escape poverty. Oxford University Press.

Kumar, D., Goel, N. K., Mittal, P. C., \& Misra, P. (2006). Influence of infantfeeding practices on nutritional status of under-five children. The Indian Journal of Pediatrics, 73(5), 417-421. https://doi.org/10.1007/BF02758565

Kumar, S., \& Berkman, L. F. (2015). Association of inadequately iodized salt use with underweight among young children in India. Asia Pacific Journal of Public Health, 27(2), 185-194.

Lee, L., Rosenzweig, M. R., \& Pitt, M. M. (1997). The effects of improved nutrition, sanitation, and water quality on child health in high-mortality populations. Journal of Econometrics, 77(1), 209-235. https://doi.org/10.1016/ S0304-4076(96)01813-1

Leslie, J. (1988). Women's work and child nutrition in the Third World. World Development, 16(11), 1341-1362. 
Lim, S. S., Fullman, N., Stokes, A., Ravishankar, N., Masiye, F., Murray, C. J. L., \& Gakidou, E. (2011). Net benefits: A multicountry analysis of observational data examining associations between insecticide-treated mosquito nets and health outcomes. PLoS Medicine, 8(9), el001091. https://doi.org/10.1371/ journal.pmed.1001091

Lumey, L. H., Stein, A. D., Kahn, H. S., van der Pal-de Bruin, K. M., Blauw, G. J., Zybert, P. A., \& Susser, E. S. (2007). Cohort profile: The Dutch Hunger Winter families study. International Journal of Epidemiology, 36(6), 1196-1204. https://doi.org/10.1093/ije/dyml26

Maccini, S., \& Yang, D. (2009). Under the weather: Health, schooling, and economic consequences of early-life rainfall. American Economic Review, 99(3), 1006-1026. https://doi.org/10.1257/aer.99.3.1006

Majra, J. P., \& Gur, A. (2009). Climate change and health: Why should India be concerned? Indian Journal of Occupational and Environmental Medicine, $13(1), 11$.

Maluccio, J. A. (2005). Coping with the coffee crisis in Central America: The role of the Nicaraguan Red de Protección Social. FCND Discussion Papers, 188 (Feb.), 44.

Maluccio, J. A., Hoddinott, J., Behrman, J. R., Martorell, R., Quisumbing, A. R., \& Stein, A. D. (2009). The impact of improving nutrition during early childhood on education among Guatemalan adults. The Economic Journal, 119(537), 734-763. https://doi.org/10.1111/j.1468-0297.2009.02220.x

Mangyo, E. (2008). The effect of water accessibility on child health in China. Journal of Health Economics, 27(5), 1343-1356.

Masset, E., Leroy, J. L., \& Frongillo, E. A. (2007). Can interventions to promote animal production ameliorate undernutrition? The Journal of Nutrition, $137(10), 2311-2316$.

Maxwell, D. (1999). The political economy of urban food security in Sub-Saharan Africa. World Development, 27(11), 1939-1953. https://doi.org/10.1016/ S0305-750X(99)00101-1

Meenakshi, J. V. (2016). Trends and patterns in the triple burden of malnutrition in India. Agricultural Economics, 47(S1), 115-134. https://doi.org/10.1111/ agec. 12304

Mengistie, B., Berhane, Y., \& Worku, A. (2013). Household water chlorination reduces incidence of diarrhea among under-five children in rural Ethiopia: A cluster randomized controlled trial. PLoS One, 8(10), e77887.

Menon, P., Bamezai, A., Subandoro, A., Ayoya, M. A., \& Aguayo, V. (2015). Ageappropriate infant and young child feeding practices are associated with child nutrition in India: Insights from nationally representative data. Maternal o Child Nutrition, 11(1), 73-87.

Miguel, E., \& Kremer, M. (2015). Worms: Identifying impacts on education and health in the presence of treatment externalities. Econometrica, 72(1), 159-217. MoHFW. (2017). India: Health of the nation's states. MoHFW Report. 
Murray, C. J. L., Vos, T., Lozano, R., Naghavi, M., Flaxman, A. D., Michaud, C., ... Lopez, A. D. (2012). Disability-adjusted life years (DALYs) for 291 diseases and injuries in 21 regions, 1990-2010: A systematic analysis for the Global Burden of Disease Study 2010. The Lancet, 380(9859), 2197-2223. https:// doi.org/10.1016/S0140-6736(12)61689-4

Myers, S. S., Smith, M. R., Guth, S., Golden, C. D., Vaitla, B., Mueller, N. D., ... Huybers, P. (2017). Climate change and global food systems: Potential impacts on food security and undernutrition. Annual Review of Public Health, 38(1), 259-277. https://doi.org/10.1146/annurev-publhealth-031816-044356

Nichter, M. (2008). Global health: Why cultural perceptions, social representations, and biopolitics matter. University of Arizona Press.

Nicklas, T. A., Baranowski, T., Cullen, K. W., \& Berenson, G. (2001). Eating patterns, dietary quality and obesity. Journal of the American College of Nutrition, 20(6), 599-608.

Oreopoulos, P., Page, M. E., \& Stevens, A. H. (2006). The intergenerational effects of compulsory schooling. Journal of Labor Economics, 24(4), 729-760.

Owusu, V., Abdulai, A., \& Abdul-Rahman, S. (2011). Non-farm work and food security among farm households in Northern Ghana. Food Policy, 36(2), 108-118. https://doi.org/10.1016/j.foodpol.2010.09.002

Parker, S., \& Skoufias, E. (2000). The impact of PROGRESA on work, leisure and time allocation. Washington, DC: International Food Policy Research Institute.

Patil, S. R., Arnold, B. F., Salvatore, A. L., Briceno, B., Ganguly, S., Colford, J. M., Jr., \& Gertler, P. J. (2014). The effect of India's total sanitation campaign on defecation behaviors and child health in rural Madhya Pradesh: A cluster randomized controlled trial. PLoS Medicine, 11(8), el001709.

Patz, J. A., Campbell-Lendrum, D., Holloway, T., \& Foley, J. A. (2005). Impact of regional climate change on human health. Nature, 438(7066), 310.

Pingali, P. (2006). Westernization of Asian diets and the transformation of food systems: Implications for research and policy. Food Policy, 32(3), 281-298. https://doi.org/10.1016/j.foodpol.2006.08.001

Pingali, P. (2007). Westernization of Asian diets and the transformation of food systems: Implications for research and policy. Food Policy, 32(3), 281-298. https://doi.org/10.1016/j.foodpol.2006.08.001

Pingali, P. (2012). Green revolution: Impacts, limits, and the path ahead. Proceedings of the National Academy of Science, 109(31), 12302-12308. https://doi.org/10.1073/pnas.0912953109

Pingali, P. (2015). Agricultural policy and nutrition outcomes-Getting beyond the preoccupation with staple grains. Food Security, 7(3), 583-591. https:// doi.org/10.1007/s12571-015-0461-x

Pingali, P., \& Sunder, N. (2017). Transitioning toward nutrition-sensitive food systems in developing countries. Annual Review of Resource Economics, 9(1), 439-459. https://doi.org/10.1146/annurev-resource-100516-053552 
Pingali, P. L., \& Ricketts, K. D. (2014). Mainstreaming nutrition metrics in household surveys-Toward a multidisciplinary convergence of data systems. Annals of the New York Academy of Sciences, 1331(1), 249-257. https://doi. org/10.1111/nyas.12597

Plessow, R., Arora, N. K., Brunner, B., Tzogiou, C., Eichler, K., Brügger, U., \& Wieser, S. (2015). Social costs of iron deficiency anemia in 6-59-month-old children in India. PLoS One, 10(8). https://doi.org/10.1371/journal. pone.0136581

Popkin, B. M. (1997). The nutrition transition and its health implications in lower-income countries. Public Health Nutrition, 1(1), 5-21.

Popkin, B. M. (1999). Urbanization, lifestyle changes and the nutrition transition. World Development, 27(11), 1905-1916. https://doi.org/10.1016/ S0305-750X(99)00094-7

Popkin, B. M. (2003). The nutrition transition in the developing world. Development Policy Review, 21(5-6), 581-597. https://doi.org/10.1111/ j.1467-8659.2003.00225.x

Popkin, B. M., Horton, S., Kim, S., Mahal, A., \& Shuigao, J. (2001). Trends in diet, nutritional status, and diet-related noncommunicable diseases in China and India: The economic costs of the nutrition transition. Nutrition Reviews, 59(12), 379-390.

Rah, J. H., Akhter, N., Semba, R. D., De Pee, S., Bloem, M. W., Campbell, A. A., ... Kraemer, K. (2010). Low dietary diversity is a predictor of child stunting in rural Bangladesh. European Journal of Clinical Nutrition, 64(12), 1393.

Rah, J. H., Cronin, A. A., Badgaiyan, B., Aguayo, V. M., Coates, S., \& Ahmed, S. (2015). Household sanitation and personal hygiene practices are associated with child stunting in rural India: A cross-sectional analysis of surveys. BMJ Open, 5(2), e005180.

Rahman, A. (2016). Universal food security program and nutritional intake: Evidence from the hunger prone KBK districts in Odisha. Food Policy, 63, 73-86. https://doi.org/10.1016/j.foodpol.2016.07.003

Rahman, A. (2017). Food elasticity estimates for rural India: Preference for food variety and between group substitutions.

Rasmussen, K. M. (2001). Is there a causal relationship between iron deficiency or iron-deficiency anemia and weight at birth, length of gestation and perinatal mortality? The Journal of Nutrition, 131(2), 590S-603S.

Reardon, T., \& Minten, B. (2011). Surprised by supermarkets: Diffusion of modern food retail in India. Journal of Agribusiness in Developing and Emerging Economies, 1(2), 134-161. https://doi.org/10.1108/20440831111167155

Reardon, T., Timmer, C. P., \& Minten, B. (2012). Supermarket revolution in Asia and emerging development strategies to include small farmers. Proceedings of the National Academy of Sciences, 109(31), 12332-12337. https://doi. org/10.1073/pnas.1003160108 
Roseboom, T., de Rooij, S., \& Painter, R. (2006). The Dutch famine and its longterm consequences for adult health. Early Human Development, 82(8), 485-491.

Roseboom, T. J., Van Der Meulen, J. H. P., Ravelli, A. C. J., Osmond, C., Barker, D. J. P., \& Bleker, O. P. (2001). Effects of prenatal exposure to the Dutch famine on adult disease in later life: An overview. Molecular and Cellular Endocrinology, 185(1-2), 93-98.

Ruel, M. T. (2003). Operationalizing dietary diversity: A review of measurement issues and research priorities. The Journal of Nutrition, 133(11), 3911S-3926S.

Semba, R. D., de Pee, S., Sun, K., Campbell, A. A., Bloem, M. W., \& Raju, V. K. (2010). Low intake of vitamin A-rich foods among children, aged 12-35 months, in India: Association with malnutrition, anemia, and missed child survival interventions. Nutrition, 26(10), 958-962.

Sengupta, A., Angeli, F., Syamala, T. S., Dagnelie, P. C., \& Schayck, C. P. v. (2015). Overweight and obesity prevalence among Indian women by place of residence and socio-economic status: Contrasting patterns from "underweight states" and "overweight states" of India. Social Science and Medicine, 138, 161-169. https://doi.org/10.1016/j.socscimed.2015.06.004

Shetty, P., Victora, C. G., Adair, L., Fall, C., Hallal, P. C., Martorell, R., ... Group, M. and C. U. S. (2012). India's diabetes time bomb. Nature, 485(7398), S14. Shrivastava, U., Misra, A., Mohan, V., Unnikrishnan, R., \& Bachani, D. (2017). Obesity, diabetes and cardiovascular diseases in India: Public health challenges. Current Diabetes Reviews, 13(1), 65-80.

Shroff, M., Griffiths, P., Adair, L., Suchindran, C., \& Bentley, M. (2009). Maternal autonomy is inversely related to child stunting in Andhra Pradesh, India. Maternal \& Child Nutrition, 5(1), 64-74.

Shroff, M. R., Griffiths, P. L., Suchindran, C., Nagalla, B., Vazir, S., \& Bentley, M. E. (2011). Does maternal autonomy influence feeding practices and infant growth in rural India? Social Science \& Medicine, 73(3), 447-455.

Sibhatu, K. T., Krishna, V. V., \& Qaim, M. (2015). Production diversity and dietary diversity in smallholder farm households. Proceedings of the National Academy of Sciences, 112(34), 10657-10662.

Singh, A., Park, A., \& Dercon, S. (2013). School meals as a safety net: An evaluation of the midday meal scheme in India. Economic Development and Cultural Change, 62(2), 275-306.

Singh, P. (2015). Performance pay and information: Reducing child undernutrition in India. Journal of Economic Behavior \& Organization, 112, 141-163.

Spears, D., Ghosh, A., \& Cumming, O. (2013). Open defecation and childhood stunting in India: An ecological analysis of new data from 112 districts. PLoS One, 8(9), e73784. https://doi.org/10.1371/journal.pone.0073784

Stein, A. D., Wang, M., Digirolamo, A., Grajeda, R., Ramakrishnan, U., Ramirezzea, M., ... Inter-, S. (2008). Nutritional supplementation in early childhood, schooling, and intellectual functioning in adulthood. Archives of Pediatrics \& Adolescent Medicine, 162(7), 612-618. 
Steyn, N. P., Nel, J. H., Nantel, G., Kennedy, G., \& Labadarios, D. (2006). Food variety and dietary diversity scores in children: Are they good indicators of dietary adequacy? Public Health Nutrition, 9(5), 644-650.

Strauss, J., \& Thomas, D. (1998). Health, nutrition, and economic development. Journal of Economic Literature, 36(2), 766-817.

Sturm, R., Ringel, J. S., \& Andreyeva, T. (2004). Increasing obesity rates and disability trends. Health Affairs, 23(2), 199-205.

Subramanian, S., \& Deaton, A. (1996). The demand of food and calories. Journal of Political Economy, 104(1), 133-162.

Swinburn, B. A., Sacks, G., Hall, K. D., McPherson, K., Finegood, D. T., Moodie, M. L., \& Gortmaker, S. L. (2011). The global obesity pandemic: Shaped by global drivers and local environments. The Lancet, 378(9793), 804-814. https://doi.org/10.1016/S0140-6736(11)60813-1

Thakur, N., Chandra, J., Pemde, H., \& Singh, V. (2014). Anemia in severe acute malnutrition. Nutrition, 30(4), 440-442.

Thior, I., Lockman, S., Smeaton, L. M., Shapiro, R. L., Wester, C., Heymann, S. J., ... Kim, S. (2006). Breastfeeding plus infant zidovudine prophylaxis for 6 months vs formula feeding plus infant zidovudine for 1 month to reduce mother-to-child HIV transmission in Botswana: A randomized trial: The Mashi Study. JAMA, 296(7), 794-805.

Thomas, D., Strauss, J., \& Henriques, M. (1991). How does mother's education affect child height? The Journal of Human Resources, 26(2), 183-211.

Townsend, R. M. (1994). Risk and insurance in village India. Econometrica, $62(3), 539-591$.

Townsend, R. M. (1995). Consumption insurance: An evaluation of risk-bearing systems in low-income economies. Journal of Economic Perspectives, 9(3), 83-102. https://doi.org/10.1257/jep.9.3.83

Victora, C. G., Adair, L., Fall, C., Hallal, P. C., Martorell, R., Richter, L., ... Group, M. and C. U. S. (2008). Maternal and child undernutrition: Consequences for adult health and human capital. The Lancet, 371(9609), 340-357.

Wang, Y. C., McPherson, K., Marsh, T., Gortmaker, S. L., \& Brown, M. (2011). Health and economic burden of the projected obesity trends in the USA and the UK. The Lancet, 378(9793), 815-825. https://doi.org/10.1016/ S0140-6736(11)60814-3

Watts, N., Adger, W. N., Agnolucci, P., Blackstock, J., Byass, P., Cai, W., ... Cooper, A. (2015). Health and climate change: Policy responses to protect public health. The Lancet, 386(10006), 1861-1914. 
Open Access This chapter is licensed under the terms of the Creative Commons Attribution 4.0 International License (http://creativecommons.org/licenses/ by $/ 4.0 /)$, which permits use, sharing, adaptation, distribution and reproduction in any medium or format, as long as you give appropriate credit to the original author(s) and the source, provide a link to the Creative Commons licence and indicate if changes were made.

The images or other third party material in this chapter are included in the chapter's Creative Commons licence, unless indicated otherwise in a credit line to the material. If material is not included in the chapter's Creative Commons licence and your intended use is not permitted by statutory regulation or exceeds the permitted use, you will need to obtain permission directly from the copyright holder.

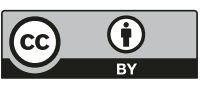

